\title{
Balanced Scorecard in SMEs: Effects on innovation and financial performance
}

\author{
Ricardo Malagueño \\ Norwich Business School, University of East Anglia, \\ Norwich Research Park, Norwich, Norfolk, NR4 7TJ, UK, (r.malagueno@uea.ac.uk) \\ Ernesto Lopez-Valeiras \\ Departamento de Economía Financiera y Contabilidad \\ Facultad de Ciencias Empresariales y Turismo, Universidad de Vigo \\ Campus Universitario As Lagoas s/n, 32004 Ourense, España, (elvaleiras@uvigo.es) \\ Jacobo Gomez-Conde \\ Departamento de Contabilidad, \\ Facultad de Ciencias Económicas y Empresariales \\ Universidad Autónoma de Madrid \\ C/ Francisco Tomás y Valiente, 5, 28049 Madrid, España, (jacobo.gomez@uam.es)
}

\begin{abstract}
Empirical research on the consequences of the use of the balanced scorecard (BSC) has mostly been conducted in large firms. Previous findings are not easily applied to the small business literature, and assumptions about the benefits of BSC for small and medium-sized enterprises (SMEs) are not based on quantitative empirical evidence. We investigated the effects of SME's use of BSC in terms of financial performance and innovation outcomes. Our arguments are based on the efficiency gains and potential flexibility losses associated with formalizing managerial practices in SMEs. We propose that the developmental stage of the firm may influence this trade-off. Based on a survey of 201 SMEs in Spain, we found that firms using BSC for feedforward control obtained better financial performance and presented higher levels of exploitative innovation. We also found that the positive effect of BSC on perceived and attained financial performance is stronger in more established SMEs.
\end{abstract}

Keywords: balanced scorecard, financial performance, innovation, small business, efficiency, flexibility

JEL Classifications: L25, M10, O31, M40, L21

Acknowledgements: We acknowledge Margaret Abernethy, Shannon Anderson, Tiago Botelho, Victor Maas, David Naranjo-Gil and the participants of II Research Forum: Challenges in Management Accounting and Control at Seville for their helpful comments. We are also grateful for the comments of conference participants at the 2016 and 2017 European Accounting Association Congress, seminar participants at the Universidad Autónoma de Madrid and attendees of the XXII Workshop on Accounting and Management Control. We acknowledge financial assistance from the Spanish Ministry of Education and Science (ECO2016-77579-C3-3-P). 


\section{Introduction}

The balanced scorecard (BSC) is one of the managerial practices most frequently used by large and small and medium-sized enterprises (SMEs) ${ }^{1}$ (Rigby and Bilodeau 2015; Cooper et al. 2017). During the last decade, considerable progress has been made on improving the implementation of the BSC within SMEs (Fernandes et al. 2006; Garengo and Bititci 2007; Hudson-Smith and Smith 2007; Wouters and Wilderom 2008; Taylor and Taylor 2014). Proponents of the BSC have suggested that SMEs might benefit extensively from using it (Kaplan and Norton 1996); nevertheless, empirical evidence of the effects of BSC use on SMEs is scarce and has generally been obtained through only a few case studies (e.g., Gumbus and Lussier 2006; Biazzo and Garengo 2012). Most research on the effectiveness of BSC was conducted in large firms and led to the recognition that this managerial practice can help firms successfully achieve their desired outcomes (Ittner et al. 2003; De Geuser et al. 2009; Micheli and Manzoni 2010; Busco and Quattrone 2015). Although important to our understanding of the consequences of using $\mathrm{BSC}$, this finding cannot be generalized to the small business literature (Bititci et al. 2012). Studies have shown that the use of managerial practices in SMEs involves specific attributes not shared with large firms (Hudson-Smith and Smith 2007). First, resource constraints, particularly on management time and expertise, mean that the routine of managerial practices is markedly more demanding for SMEs than for larger firms (Ates et al. 2013). Second, SMEs' lack of a monetary safety net and their high reliance on fewer customers require their managers to be over-attentive to the evolution of short-term performance measures (Hudson-Smith and Smith 2007). Finally, the flatter and more flexible structure of SMEs typically requires employees to perform multiple roles, with unclear boundaries and job responsibilities. Compensation systems and employee performance appraisals are less formalized and objective in SMEs (Cardon and Stevens 2004).

Particularly challenging for SMEs is the tension between efficiency versus flexibility emerging from the formalization of managerial practices (Chowdhury 2011; Patel 2011). If SMEs benefit from efficiency gains accompanying the use of the BSC, it may come at a cost that is usually associated with significant constraints on firm flexibility (Benner and Tushman 2003). Therefore, a study of the effects of the use of the BSC in SMEs requires more than a simple appreciation of firm efficiency; it requires the thoughtful consideration of its effects on

\footnotetext{
${ }^{1}$ Evidence shows that the BSC adoption rate is $60 \%$ among large firms and $25 \%$ to $31 \%$ among small and medium size firms (CIMA 2009).
} 
flexibility. This commonly experienced trade-off (Ebben and Johnson 2005; Eisenhardt et al. 2010) concerns SMEs to a great extent because those firms are highly dependent on flexible structures in their efforts to develop exploratory initiatives (Freel 2000; Glaser et al. 2015). ${ }^{2}$

This study uses a combination of archival and survey data gathered from 201 senior managers to investigate the effects of the use of the BSC in SMEs. Drawing on the trade-off between the efficiency gains and the flexibility losses introduced by this formal managerial practice, we argue that the use of the BSC for feedforward control positively influences financial performance and exploitative innovation at the expense of a reduction in exploratory innovation. Second, we take into account the importance of the developmental stage of the firm when describing the use of managerial practices (Davila et al. 2009) and their influence in SMEs (Brinckmann et al. 2010; Rosenbusch et al. 2011). We propose that the firm's development stage may influence the efficiency-flexibility trade-off resulting from the use of the BSC.

This article contributes to the small business and organizational control literature by extending prior research on the consequences of BSC use in SMEs. It aims to bring more empirical evidence to the scarce organizational control literature that has explored the effects of formal modes of control on SMEs (Wijbenga et al. 2007; Voss and Brettel 2014). Additionally, it adds to the innovation and small business literature by responding to calls for a better understanding of the relationship between technological innovations (i.e., process and product innovation) and managerial practices in SMEs (Hervas-Oliver et al. 2016). It investigates the factors that influence innovation in SMEs (Chang and Hughes 2012) by postulating the use of BSC as a key driver that is employed to control organizational tensions, thus facilitating communication and assisting coordination. We show how the use of BSC might affect the different innovation outcomes of SMEs (i.e., exploitative innovations vs. exploratory innovations), and consequently, this study illustrates how SMEs may benefit from the use of BSC in their attempts to be competitive. Finally, this paper scrutinizes the influences of the theoretically meaningful, yet under-researched, moderating effect of a firm's developmental stage on the relationship between BSC and performance outcomes. It studies the contributions of BSC to both young and established SMEs. Hence, this research investigates, in greater depth, the nature of the relationship between control and innovation and

\footnotetext{
2 It has been suggested that managers of large firms could address the efficiency-flexibility trade-off by promoting spatial separation (e.g., structurally separate R\&D units) (Benner and Tushman 2003), temporal differentiation (Nickerson and Zenger 2002) or strategic alliance networks (Lin et al. 2007). The small business literature has shown that these options are less accessible to SMEs and that top management teams and the managerial practices supporting their decision-making play a pivotal role in managing the trade-off (Lubatkin et al. 2006; Volery et al. 2015).
} 
financial performance, filling an important gap and shedding new light on this complex relationship.

\section{Literature review and hypotheses}

\subsection{Balanced scorecard}

BSC represents a multi-perspective framework that relies on a set of metrics (i.e., financial and nonfinancial, long and short term, and internal and external). The original BSC framework was characterized by the presence of four perspectives - financial, customer, internal process, and learning and growth - which contained different sets of metrics that were adapted to industries and firms (Kaplan and Norton 1996). As a (strategic) performance measurement system (PMS) (Garengo et al. 2005; Bisbe and Malagueño 2012), this tool allows firms to translate strategy into achievable objectives. A critical assumption of BSC is that each performance measure is part of a balanced cause-and-effect relationship in which leading measures (e.g., nonfinancial, drivers of future financial performance) drive lagging measures (e.g., financial, results of past actions). By tracking a firm's progress against these measures, managers and employees can accomplish the firm's mission by identifying and correcting under-performing perspectives. ${ }^{3}$

A number of frameworks have been proposed in the literature to assess the appropriateness of PMS and consequently their effectiveness. Several of these frameworks emphasize applying design features to evaluate a firm's existing PMS (Evans 2004). For instance, Medori and Steeple (2000) suggest that PMS should be evaluated based on six stages: the selection of organizational critical success factors, the matching of strategic requirements and priorities, the selection of measures, the audit, implementation, and maintenance. Other studies, however, show the importance of accounting for the use rather than merely the design when assessing PMS (Koufteros et al. 2014; Bititci et al. 2015). Those studies note that firm performance is a consequence of how practices are conducted rather than the practice itself. In this vein, prior research showed that the adoption of BSC does not imply that it is manifested in more than a ritual manner or that it is practised by organizational participants (Garengo and

\footnotetext{
${ }^{3}$ Even though early studies questioned the suitability of BSC for SMEs (McAdam 2000; Hoque 2003), more recent research developments on the adoption of managerial practices suggest that the adoption and use of BSC are related to the complexity of the firm rather than to size-related factors (Kallunki and Silvola 2008; Davila et al. 2009).
} 
Sharma 2014). Therefore, in order to understand the effects of BSC on SMEs, it is fundamental to study its use rather than its mere presence or availability.

\subsection{Balanced scorecard for feedforward control}

In our research, we examine the use of BSC for feedforward control, as opposed to its traditional use for feedback control (Grafton et al. 2010; Pavlov and Bourne 2011). The feedforward use of BSC involves the application of BSC's formal calculative framework to the constant examination of variances between actual and pre-set targets, aiming to facilitate organizational debates and to promote knowledge sharing and continuous learning. Researchers have noted that feedforward control is preventive, anticipating threats and leading operational changes (Pavlov and Bourne 2011). In contrast, the use of BSC for feedback control involves the application of BSC's formal calculative framework to the sporadic examination of variances between actual and pre-set targets, aiming at the evaluation of past performance. Feedback enhances monitoring of operations and promotes immediate corrective actions (Ebben and Johnson 2005; Pavlov and Bourne 2011). ${ }^{4}$

A major assumption underpinning the use of BSC among large firms and SMEs is that it has a positive effect on firm performance (Gumbus and Lussier 2006; De Geuser et al. 2009; Cooper et al. 2017). To date, research on the contributions of BSC to large organizations has suggested a positive association between the feedforward use of BSC and the development of new capabilities and exploratory initiatives (Grafton et al. 2010, Pavlov and Bourne 2011). In this paper, we postulate differently, as we discuss the characteristics of SMEs that create a unique context for the use of BSC.

\subsection{Balanced scorecard: efficiency gains and flexibility losses}

Drawing on configuration theory, we argue that the feedforward use of BSC supports firm efficiency. In SMEs, owner-managers are at the centre of most strategic decisions. They define the firm's priorities and the pace at which those strategies are implemented. It is

\footnotetext{
4 Admittedly, to be consistent with prior literature, these labels could also be 'interactive' and 'diagnostic' (Bisbe and Malagueño 2009; Koufteros et al. 2014). Interactive and diagnostic uses have been employed to examine managerial control practices in large firms. Whereas the interactive use of controls involves double-loop learning, the diagnostic use concerns single loop learning. We opt not to introduce these labels into our discussion of small business and instead base our types on the extant prior literature. Several researchers in the small business literature have shown that the behavioural and organizational effects of managerial practices are deeply associated with how they are used. Among those studies, analogous typologies were examined, including loose / flexible and tight (De Massis et al. 2015), organic and mechanistic (McAdam et al. 2014), and feedback and feedforward (Ebben and Johnson 2005).
} 
expected that a greater emphasis of owner-managers on the BSC framework directs employees' limited attention towards the key priorities that require action. The continuous use of BSC creates a platform for the broad evaluation of different dimensions of the firm (Garengo et al. 2005). It improves organizational control by enhancing goal clarity among employees and creating an accountability structure in which individuals are assigned to be owners of metrics (Wouters and Wilderom 2008; Busco and Quattrone 2015). Managerial attention to the BSC introduces formalization into SMEs' traditionally informal operational control structures (Cardinal et al 2004), facilitating the strategic alignment of employees so that they can efficiently pursue the firm's intended strategies (Garengo and Bititci 2007). Additionally, the use of BSC for feedforward control triggers regular meetings and discussions between managers and subordinates to evaluate the calculative information contained in the BSC (Pavlov and Bourne 2011). Such gatherings aim to predict likely outcomes arising from the current course of action, and they become opportunities to interpret and integrate knowledge so that efficiency gains made by individual employees are institutionalized and turned into organizational assets (Jones and Macpherson 2006; Grafton et al. 2010). Enhanced efficiency associated with the use of managerial practices has long been recognized as leading to better financial performance (Evans and Davis 2005).

Efficiency is also a prerequisite for the successful development of exploitative innovation. Exploitative innovation entails incremental refinements, continuous improvement and implementation (Volery et al. 2015). It requires managers to deploy a profound understanding of the business, its different perspectives, employees' know-how and organizational resources (Branzei and Vertinsky 2006; Volery et al. 2015). The structure and comprehensiveness of the information contained in the BSC frame the managers' distinct cognitive representations of the organization's strategy, thus influencing the way managers access information, include issues in their strategic agendas and subsequently make decisions. BSC supports cognitive reasoning by focusing managerial attention and framing managers' heuristics and reasoning (Bisbe and Malagueño 2012; Cheng and Humphreys 2012). Vermeulen (2005) finds that two of the main barriers to the development of exploitative innovations in SMEs are the lack of legitimacy of such activities and the continuous reallocation of resources. The managerial discussions introduced by the use of BSC over metrics and results legitimizes initiatives on particular aspects of the business that require improvements (Ates et al. 2013; Busco and Quattrone 2015). For instance, the permanent evaluation of performance against targets related to the customer perspective of the BSC may assist managers of SMEs in keeping track of competitors and understanding what they are 
offering, as well as why current customers do or do not buy and how satisfied they are. Additionally, BSC sorts targets into different perspectives, reducing the continuous reallocation of resources and providing a framework for measures to be aligned with critical strategies (Gumbus and Lussier 2006; Wouters and Wilderom 2008). Therefore, the use of BSC is likely to encourage the development of exploitative innovations around certain issues that are accounted for in the business strategy. Following the above arguments, we propose the following hypotheses:

H1a: The use of the balanced scorecard by SMEs is positively associated with financial performance.

H1b: The use of the balanced scorecard by SMEs is positively associated with exploitative innovations.

Flexibility is a prerequisite for the successful development of exploratory innovation. Exploratory innovation entails moving beyond current paradigms and existing product portfolios by experimenting and taking risks (Volery et al. 2015).

Several researchers studying large firms have suggested that the use of BSC for feedforward purposes assists firms in converting tacit into explicit knowledge, thus helping them externalize and combine such knowledge to support the development of exploratory innovations, which respond to and drive environmental trends (e.g., Tuomela 2005; McCarthy and Gordon 2011). This use of BSC is recognized for its ability to promote knowledge sharing and continuous learning, which revolve around strategic uncertainties and opportunities (Grafton et al. 2010). In large firms, it changes the formal performance measurement routine, introducing flexibility were bureaucracy usually prevails. The discussions resulting from the feedforward use of BSC allow top managers to get involved in operational activities, enabling the identification of key success factors that support the more comprehensive (re)formulation of strategies and plans (Bisbe and Malagueño 2012); these discussions also engage organizational members (including lower level employees) in the scanning of market opportunities (Grafton et al. 2010).

However, in SMEs, the flatter structure, faster communication and greater informality of routines and procedures (Srećković 2017) make it more difficult to identify those attributes of the use of BSC that stimulate the development of exploratory innovations in large firms. Owner-managers, usually key drivers of exploratory initiatives in SMEs (Glaser et al. 2015; 
Volery et al. 2015), are already deeply involved in the organizational processes and consequently might not benefit as much as managers of large firms from the learning experience that might arise from the evaluation of formal BSC. Additionally, exploratory initiatives in SMEs are mostly carried out by a rather informal learning-by-doing process; there is less focus on $R \& D$, or even a rather non-R\&D-oriented process (Hervas-Oliver et al. 2016). Its flexible structures permit spontaneous discussions and experimentation. Shorter lines of interaction within the firm make the dissemination of tacit knowledge easier in small firms than it is in larger firms (Koskinen and Vanharanta 2002). The use of BSC as a formal managerial practice could easily be confounded by firm participants as another layer of control in SMEs, weakening the flexible communication and control structures that are already in place. Finally, limited resources - in terms of time management and human resources - do not allow managers and subordinates to use formal performance evaluation meetings to deeply scan the external environment to explore new opportunities beyond existing products, markets and customers. In this vein, field study and interviews conducted by Ates et al. (2013) concluded that performance management processes in SMEs are particularly narrow and dedicate the most attention to short-term financial and operational activities, failing to identify and scan external factors that might affect their business. In brief, we predict that the attributes of the use of BSC that stimulate exploratory innovation in large firms are not similarly beneficial to SMEs. Thus,

H1c: The use of the balanced scorecard by SMEs is negatively associated with exploratory innovation.

2.4 Developmental stage and the effects of the balanced scorecard

We argued that not all SMEs benefit equally from the use of BSC. A common assertion is that formalization in young firms reduces role ambiguity, decreases the costs of coordination and improves decision-making (Cosh et al. 2012). However, several researchers have noted that the lack of structure in young firms diminishes the efficiency outcomes of formal managerial practices (Chowdhury 2011). Younger SMEs that are resourceful enough to adopt and use BSC often face operational and strategic problems that are not easily predictable. These firms often need to establish managerial and manufacturing processes while lacking internal and external information (Brinckmann et al. 2010). As a result, young SMEs do not have welldefined routines, structures, and processes that discipline firm actions and support fullimplementation of more sophisticated managerial practices (López and Hiebl 2015). That is to 
say, "it is difficult or impossible to establish performance measures for activities with which the organization has no or very little experience" (Nørreklit, 2000, p.72). Consequently, the improved organizational efficiency that is expected to arise from the use of BSC would not be fully achieved in those enterprises.

In contrast, more established SMEs possess the established routines that support the use of sophisticated managerial practices. These firms have already passed their cycle of experimentation and have established processes and products. The feedforward use of BSC provides a framework that enhances learning within the capabilities of the firm, allowing it to be more efficient. It promotes efficiency by diffusing coded learning from past experience across the firm (Davila et al. 2009). Consistent with this argument, Brinckmann et al. (2010) conclude that the higher levels of uncertainty and ambiguous information faced by young SMEs causes the use of planning practices to render lower contributions to those firms than it does for more established small firms. In summary, we expect that firms that have reached later developmental stages will be better equipped to appropriate potential gains in efficiency from the use of BSC. Thus,

H2a: The positive effect of the balanced scorecard on financial performance depends on the firm's stage of development, such that the effect is stronger in more established firms.

$\boldsymbol{H} \boldsymbol{2 b}$ : The positive effect of the balanced scorecard on exploitative innovation depends on the firm's stage of development, such that the effect is stronger in more established firms.

The creation of a new firm intrinsically implies novelty (Davila et al. 2012). In younger firms, organizational culture centres on core values and attitudes, such as the inclination to take risks, experimentation, proactivity towards marketplace opportunities and tolerance of failure (Anderson and Eshima 2013). Managers of younger firms are often said to rely more on heuristics and less on rational and formal decision-making tools that would require time and would postpone decisions (Busenitz and Barney 1997). Organizational culture, organic structures and the use of heuristics in decision-making better position younger firms to generate exploratory innovations and take advantage of (benefit from) fleeting "windows of opportunity" (Hill and Rothaermel 2003).

In more established SMEs, core competencies often evolve into core rigidities (LeonardBarton 1992), which discourage experimentation and risk-taking (Danneels 2002). Over time, firms tend to endorse innovative initiatives that build upon their existing capabilities, so that 
exploration spontaneously decreases (Branzei and Vertinsky 2006). It is expected that formal managerial practices, such as the BSC, that could be seen as obstacles to creative flexibility in young firms are, in more established firms, considered part of established routines, as the extensive reliance on heuristics in strategic decision-making that is of great advantage for younger firms is insufficient for these firms. Thus,

H2c: The negative effect of the balanced scorecard on exploratory innovation depends on the firm's stage of development, such that the effect is weaker in more established firms.

\section{Data and methodology}

\subsection{Sample, survey and respondents}

To test our hypotheses, we draw on an original survey and archival data gathered from the Bureau Van Dijk database (Iberian Balance Sheet Analysis System - SABI). The sample was selected from the food and beverage industry (NACE codes 10 and 11) in Spain. We employed a procedure of stratified sampling by size and industry from the SABI database. We selected firms with a minimum of 10 employees to exclude those small firms that lack the minimal business structure required to implement formal sophisticated managerial practices (McCarthy and Gordon 2011). A total of 5,814 firms were identified. Of these, only 2,979 provided a contact email.

The survey was conducted between February and May 2011. Following Dillman's (2000) guidelines for surveys, e-mails were initially sent to all firms to verify the accuracy of the data. Second, the chief executive officer (CEO) of the firm was asked for his or her willingness to participate in this research. Third, a cover letter presenting the study was sent to the firms, in addition to the link to the questionnaire. Fourth, in an attempt to increase the response rate, we sent three follow-up e-mails, and finally, there was a series of phone calls to ask those who had not yet done so to complete the questionnaire. The resulting useable sample for statistical testing included 201 SMEs. $^{5}$

Our research design required us also to capture objective secondary data on firm performance and other control variables for the years $2011(\mathrm{t}+1), 2012(\mathrm{t}+2)$ and $2013(\mathrm{t}+3)$.

\footnotetext{
${ }^{5}$ The sample for this study is part of a larger research project. Only firms that reported 10 to 250 employees in their financial statements were selected for this research paper. We acknowledge that the reliance of this paper on a single industry constrains generalizations of our findings. An important advantage of this choice is that analysis of a single industry presents higher internal validity than multi-industry analysis, as a number of spurious effects can be better controlled (Ittner et al. 2003).
} 
We collected this information from the firms' financial statements published by SABI. We completed the data collection in the last quarter of 2014.

Descriptive statistics of the sample are presented in Table 1. Details on the survey questions are included in Appendix A.

[Insert Table 1 about here]

A two-step analysis was conducted to test for non-response bias. Respondents were first compared with non-respondents in terms of sample characteristics (size, location, subindustry). Next, early and late respondents were compared to detect any differences in the mean score of each variable. Using chi-square statistics, no significant differences $(p>0.10)$ were found, supporting the absence of significant non-response bias.

We checked for the presence of common-rater bias by conducting Harman's single-factor test on the questions used to form the constructs. Harman's test assumes that, if a single or common factor that captures the majority of the covariance among the variables emerges from the factor analysis, there is strong evidence of common-rater bias (Podsakoff et al. 2003). The factor solution yielded nine factors with eigenvalues greater than 1.0. The first factor explained $21.01 \%$ of the total variance. We also used archival data for dependent and control variables, supporting the absence of significant single-source bias.

We assessed content and construct validity to establish the validity of the survey items (Nunnally 1978). Content validity was evaluated through (i) a review of questions for face validity; (ii) the process of variable construction; and (iii) the computation of an empirical measure of internal consistency. Meanwhile, construct validity was analysed through (i) identifying an appropriate domain of items underlying the construct and employing validated measures where possible; (ii) factor analyses to support the unidimensionality of the constructs; and (iii) the absence of significant cross-loadings in support of discriminant validity.

We have performed the following tasks to conduct this analysis. First, as far as possible, all constructs were measured using established and reliable scales. Second, a pretest was performed based on the preliminary edition of the questionnaire; the participants in the pretest consisted of twelve academics connected to the management field, three managers of firms in the sector and two managers from outside the sector. All of the participants made proposals and validated the final version of the questionnaire before its release. In general, in the review process, the experts recommended shortening and abbreviating the questionnaire as much as 
possible. Third, to help establish both content and construct validity, empirical tests suggested by Nunnally (1978) were performed. Table 2 shows the factor analyses employed to construct the variables. Unidimensionality was tested by the Kaiser-Meyer-Olkin statistics (KMO $>0.5)$ and Bartlett's test on item correlation (Bartlett's test=0.00). Reliability was checked using Cronbach's alpha $(\alpha>0.7)$.

\subsection{Measures}

\subsubsection{Dependent variables}

We use change in sales per employee and perceived performance as measures of financial performance. Changes in sales per employee (Bromiley and Harris 2014) were based on data taken from annual financial statements gathered primarily from the SABI database. We observe a time period of three years. Year " $\mathrm{t}$ " refers to the year 2010 . We calculate $t+1, t+2$, and $t+3$ changes in sales per employee after $t$ (e.g., $\mathrm{S}_{t+2}-\mathrm{S}_{t}$; where $\mathrm{S}_{t}$ is sales per employee in 2010 and $\mathrm{S}_{t+2}$ is sales per employee in 2012). ${ }^{6}$ Perceived performance is a self-reported variable, measured using an adapted version of the instruments developed by Kaynak and Kara (2004). Factor analysis results indicated that items loaded on one factor with an eigenvalue greater than 1.0. The factor score was introduced into the analysis as a dependent variable.

The measure for exploitative innovation is adapted from Jansen et al. (2006) and comprises four items. It is viewed as an outcome of the innovation process. We measure it by analysing the changes in product design and/or packaging and the changes or improvements in existing products. We used the scoring coefficients of the factor analysis to generate the factor score as a proxy for exploitative innovation.

The measure for exploratory innovation is also adapted from Jansen et al. (2006), and it comprises five items. It is viewed as an outcome of the innovation process. We measured it by analysing the new products' importance and novelty and the capacity of innovations to change the market structure, create new markets and make the existing product obsolete. We used the scoring coefficients of the factor analysis to generate the factor score as a proxy for exploratory innovation.

\footnotetext{
${ }^{6}$ For comparability, we include the standardized variables in the models.
} 


\subsubsection{Independent variable}

The variable use of balanced scorecard indicates the extent to which the firm employs BSC as a feedforward rather than as a feedback control tool. First, respondents were asked about the adoption of BSC. ${ }^{7}$ If BSC was not adopted, respondents were guided to the next section of the questionnaire and all items related to the use of BSC were scored zero. Out of the 201 respondents, 70 (35\% of the sample) confirmed that they had adopted BSC. The variable use of balanced scorecard was assessed using a multi-scale instrument based on the extant literature (Bisbe and Malagueño 2009; Grafton et al. 2010). A summated scale was created by adding the scores of four items assessing learning, creativity, discussion and managerial attention. Factor analysis converged on one factor with an eigenvalue greater than 1.0 .

\subsubsection{Moderating variable}

Developmental stage of the firm was measured using years since foundation (i.e., age) (Brinckmann et al. 2010).

[Insert Table 2 about here]

\subsubsection{Control variables}

The following control variables were included in the analysis due to their expected association with the use of BSC and firm innovation, development stage and performance: (i) implementation of the balanced scorecard; ${ }^{8}$ (ii) family firm; (iii) strategy; (iv) exports; (v) customer concentration; (vi) hostility; (vii) R\&D on sales; (viii) ISO 14000 certification; (ix) sales; (x) R\&D collaboration; (xi) assets; (xii) audited firm; (xiii) information and communications technology (ICT); (xiv) intangibles to total assets; (xv) cash to short liabilities; (xvi) R\&D employees; (xvii) short-term liabilities; and (xviii) employees. All control variables are defined in Appendix B.

\footnotetext{
${ }^{7}$ For content validity, we also asked in the survey whether the company had adopted budgets (the most extended control system among SMEs) and strategic planning, so that the respondents were aware that they were being asked about a balanced scorecard.

${ }^{8}$ We thank an anonymous SBE reviewer for signalling to the importance of this variable in the research model.
} 
Table 3 displays descriptive statistics on all of the variables for the full sample, BSC adopters sample and BSC non-adopters sample. Table 4 presents the correlation matrix.

[Insert Table 3 about here]

[Insert Table 4 about here]

3.3 Analytical models

The hypothesized links are analysed using OLS regressions. First, we propose the following models to assess the predicted associations in H1a (model 1), H1b (model 2), and H1c (model 3): $:^{9}$

Financial perf. $=\beta_{0}+\beta_{1}$ BSC $+\gamma \sum$ Controls $+\varepsilon$,

Exploitative innov. $=\beta_{0}+\beta_{1}$ BSC $+\gamma \sum$ Controls $+\varepsilon$,

Exploratory innov. $=\beta_{0}+\beta_{1} B S C+\gamma \sum$ Controls $+\varepsilon$,

Second, the hypothesized links in $\mathrm{H} 2 \mathrm{a}, \mathrm{H} 2 \mathrm{~b}$ and $\mathrm{H} 2 \mathrm{c}$ require the inclusion of interaction terms (development stage). The following three models are used:

Financial perf. $=\beta_{0}+\beta_{1} B S C+\beta_{2}$ Devel. stage $+\beta_{3} B S C *$ Devel. stage $+\gamma \sum$ Controls $+\varepsilon$,

Exploitative innov. $=\beta_{0}+\beta_{1} B S C+\beta_{2}$ Devel. $+\beta_{3} B S C *$ Devel. stage $+\gamma \sum$ Controls $+\varepsilon$,

Exploratory innov. $=\beta_{0}+\beta_{1} B S C+\beta_{2}$ Devel. stage $+\beta_{3} B S C *$ Devel. stage $+\gamma \sum$ Controls $+\varepsilon$, (6)

\footnotetext{
${ }^{9}$ The effect of innovation on the long-term profitability of a firm may be substantial; however, in this research we only assess the performance implications of the use of BSC in the short- and mid-terms. Thus, the effects of innovation on financial performance are not tested.
} 


\section{Results}

\subsection{Hypotheses testing}

Table 5 displays the effects of the use of BSC on financial performance (model 1), exploitative innovation (model 2), and exploratory innovation (model 3). The equations detailed in these tables include the variables of interest and a set of control variables.

The results show that the use of BSC is positively associated with the change in sales per employee $_{t+2}(\beta=0.297$, S.E. $=0.163, p<0.05)$ and the change in sales per employee ${ }_{t+3}(\beta=0.287$, S.E. $=0.139, \mathrm{p}<0.05)$. These results provide support for H1a and indicate that firms using BSC for feedforward control present higher financial performance after $\mathrm{t}+2$ and $\mathrm{t}+3$ years than firms not using BSC or firms using BSC for feedback control.

Table 5 also displays the effect of the use of BSC on exploitative and exploratory innovations. The effect of the use of BSC on exploitative innovation is positive and significant $(\beta=0.206$, S.E. $=0.125, p<0.05)$, supporting H1b, while the association between the use of BSC and exploratory innovation is negative but not significant $(\beta=-0.018$, S.E. $=0.123, p>0.05)$. Thus, H1c is not supported. Combined, these results suggest that the use of BSC for feedforward control helps organizations to be more efficient in their ability to develop exploitative innovations without reducing exploratory innovations.

\section{[Insert Table 5 about here]}

$\mathrm{H} 2 \mathrm{a}$, tested in model 4 (Table 6), posits a positive effect of the interaction between the use of BSC and the development stage on financial performance. ${ }^{10}$ The interaction is positive and statistically significant on change in sales per employee $(t+1: \beta=0.329, S . E .=0.091, p<0.01$; $\mathrm{t}+2: \beta=0.367$, S.E. $=0.094, \mathrm{p}<0.01$; and $\mathrm{t}+3: \beta=0.289$, S.E. $=0.079, \mathrm{p}<0.01$ ), providing support for H2a. Consequently, the effect of the use of BSC in SMEs on financial performance is influenced by the development stage, such that higher financial performance is observed in more established firms using the BSC for feedforward control.

$\mathrm{H} 2 \mathrm{~b}$ is tested in model 5 and predicts a positive effect for the interaction between the use of BSC and development stage on exploitative innovation. The effect is positive but non-

\footnotetext{
${ }^{10}$ To avoid issues of multicollinearity, variables for the use of BSC and development stage were mean centred before creating the interaction term.
} 
significant $(\beta=0.038$, S.E. $=0.077, \mathrm{p}>0.05)$. Finally, H2c predicts a positive effect of the interaction between the use of BSC and development stage on exploratory innovation. The results presented in model 6 are not significant $(\beta=-0.033$, S.E. $=0.075, p>0.05)$. Thus, H2b and $\mathrm{H} 2 \mathrm{c}$ are not supported. Contrary to our expectations, these results suggest that the development stage does not explain variations in the relationship between the use of BSC and innovations (exploitative and exploratory).

\section{[Insert Table 6 about here]}

Overall, Tables 5 and 6 support the arguments that SMEs benefit positively from using the BSC and that the development stage moderates the relationship between the use of BSC and financial performance.

4.2 Additional analyses and robustness checks

To test the stability of our results, we reran our models without control variables. Methodologists have pointed out that there are issues of validity surrounding the use of control variables, especially when using a large number of control variables (Schjoedt and Bird 2014). Panels A and B in Table 7 depict the results of Models 1 to 6 without control variables. The results obtained for all but one relationship are consistent with our primary analysis. ${ }^{11}$

As an additional robustness check, we also ran untabulated analyses using changes in net income as a dependent variable of financial performance. The results remained unchanged.

[Insert Table 7 about here]

\section{Discussion}

We began this research paper by noting the lack of quantitative empirical research on the consequences of the BSC on SMEs and the unsuitability of applying results from large firms to the small business literature. Drawing on the trade-off that arises from the efficiency gains

\footnotetext{
${ }^{11}$ We checked whether the incremental variances in the explained variables that stem from the control variables are statistically significant. In models 1 to $6, \Delta \mathrm{R}^{2}$ (ranging from 0.179 to 0.465 ) are significant to all cases $\left(\mathrm{p}<0.01\right.$ ). $\Delta$ Adjusted $\mathrm{R}^{2}$ (ranging from 0.073 to 0.400$)$ are also significant $(\mathrm{p}<0.01)$, with the exception of "Perceived performance" models.
} 
recognized in prior case-based research and the potential losses resulting from the inflexibilities introduced by this formal managerial practice, we investigated the effects of the use of BSC by SMEs in terms of financial performance and innovation outcomes. More specifically, we examined the extent to which the use of BSC for feedforward control influences financial performance and exploitative and exploratory innovations. We argued that these effects are dependent on the developmental stage of the firms.

Based on a survey of 201 SMEs in the food and beverage sector in Spain, we found that SMEs using BSC for feedforward control obtained better financial performance. This higher performance is neither perceived by managers nor attained immediately, but the use of BSC for feedforward control has a positive lagged effect on the sales of SMEs over two and three years. This result contributes to the small business and organizational control literature by offering more empirical evidence on the effects of formal modes of control on SMEs (Wijbenga et al. 2007; Voss and Brettel 2014). On the one hand, these results provide empirical evidence of the positive implications of the use of BSC, thus supporting claims about the benefits of BSC (Kaplan and Norton 1996). On the other hand, these findings signal major challenges for SMEs that aim to adopt and use BSC. First, they reveal that tangible gains in financial performance cannot be expected immediately. This is in accordance with studies in the small business literature indicating that the extent of the use of sophisticated management practices, such as activity based costing, is positively associated with firm financial performance in terms of growth over two years (Jänkälä and Silvola 2012). Second, it suggests that the use of BSC in the way that leads to enhanced financial performance (i.e., use for feedforward) requires high levels of managerial attention and employee engagement, resources that are commonly constrained in SMEs (Garengo et al. 2005).

We also found that SMEs using BSC for feedforward presented higher levels of exploitative innovation. Consequently, gains in efficiency that result from the use of BSC are not restricted to financial outcomes; they are also reflected in the incremental development of existing organizational capabilities. These findings are consistent with claims that increases in process management practices promote incremental innovation (Benner and Tushman 2003). Additionally, by highlighting the characteristics of BSC that provide innovation efficiency, our research illustrates a highly diffused managerial practice that can offer the necessary conditions for decentralized decision-making managed via formal structures and written plans that support superior ability to innovate (Cosh et al. 2012; Srećković 2017).

Contrary to our expectations, we did not find that the use of BSC by SMEs is negatively associated with exploratory innovation. Our primary analysis (shown in Table 5) suggests that 
the use of certain managerial practices might differently affect innovation outcomes in SMEs (Hervas-Oliver et al. 2016). First, this result differs from those of studies in large firms that point to the contributions of the use of BSC to the development of new capabilities (Grafton et al. 2010). Therefore, it validates our concern that prescriptions about the use of BSC put forward for large firms are not easily translated to SMEs. Second, this finding highlights the importance of differentiating the implications of $\mathrm{BSC}$ on innovation in terms of specific orientations (i.e., exploitative versus exploratory) and therefore introduces a key variable that explains previous claims about the desirable contribution of the BSC to innovation (e.g., Garengo et al. 2005; Bititci et al. 2012). Additional analysis without control variables shows a positive relationship between the use of BSC and exploratory innovations. We attribute this finding to the non-controlled effects of strategy, R\&D sales, R\&D collaboration, and the intangible to total assets ratio. Previous literature has shown that such variables have positive effects on the ability of a firm to innovate. For instance, Eggers et al. (2014) argue that more collaboration in product development will support higher levels of exploratory innovation in SMEs.

In examining the performance implications of the relationship between the BSC and SMEs' developmental stages, we found that more established SMEs perceive and attain higher financial performance. As per our previous arguments, and in line with the argument that the development stage moderates the relationship between planning practices and firm performance (Brinckmann et al. 2010), these results suggest that other managerial structures usually practised by established firms should be in place to support the effective use of BSC (López and Hiebl 2015). Additionally, our results suggest a less important role for the developmental stage of the SMEs than we initially expected, as we did not find that it moderated the relationship between the use of BSC and innovation, either exploitative or exploratory. These results reveal that the improvements in efficiency introduced by the use of BSC and reflected in exploitative innovations are not particular to either young or established SMEs. Furthermore, the results suggest that regardless the SME's stage of development, the use of BSC is not, by itself, sufficient to encourage and support the development of investigation, experimentation and risk-taking.

Some limitations of our study point to additional directions for future research. First, in this study we regarded BCS as a multi-perspective framework that relies on a set of metrics. However, we did not explore the informational content within the BSC. Previous literature has suggested that the composition and presentation of metrics within the balanced scorecard have differential impacts on managers' judgements (Cheng and Humphreys 2012). Further research 
could examine whether the different configurations of BSC could better explain variations in SMEs performance. Second, we developed our study using a sample composed of SMEs in the food and beverage industry, which is a mature, stable and capital-intensive industry. Given the specificities of our sample, generalization of the results of this study should be made with caution. It is likely that, in a context with more technologically intensive firms, the influence of BSC on innovation might be constrained. In this regard, Covin and Slevin (1989) highlight the significant role of informal controls (rather than formal controls) for SMEs operating in environments with high technological competition. Third, in our study, we examined BSC as an isolated practice. Most often, firms do not employ individual managerial practices as isolated systems (CIMA 2009) but rather tend to use numerous practices in combination - in the context of a complex set - that collectively constitute managerial packages (Malmi and Brown 2008). By taking a package approach, future research will be able to develop a broader understanding of the performance implications of the BSC. Fourth, in this research we examined the effects of BSC on innovation, overlooking innovation initiatives that emerge beyond organizational boundaries (Spithoven et al. 2013). We used a control variable to account for the extent to which the SMEs in our sample collaborate with other firms in terms of innovation. Nevertheless, the understanding of whether and how BSC supports interorganizational innovation projects was beyond the scope of our research. Given the importance of such collaborations for the development of innovations in SMEs, we encourage studies investigating the performance implications of BSC to account for its use in such collaborations. Finally, the results of this research are based on a survey and thus suffer from cross-sectional and survey-related limitations. Longitudinal research might provide additional support for our findings.

\section{Conclusions}

In sum, this study draws on the small business, organizational control and innovation literature to explain the effects of the use of BSC by SMEs. The results show that SMEs benefit from the use of BSC for feedforward control, such that firms that use it present higher financial performance and higher exploitative innovation outcomes. This positive effect on financial performance is stronger for more established firms. Consistent with the idea that the use of managerial planning practices supports firm efficiency (Benner and Tushman 2003; Brinckmann et al. 2010) and with prior case-based research that have noted the benefits of BSC, our study provides quantitative empirical evidence that BSC can play a relevant role in 
SMEs. Our research offers some meaningful implications for SME managers who wish to consider adopting and using BSC. In this sense, it shows that specific uses of BSC represent effective means of enhancing organizational efficiencies without apparent reductions in flexibility. Hence, our findings offer SME managers suggestions concerning which uses and designs of managerial practices might be suitable for pursuing specific strategic priorities. 


\section{Appendix A - Abbreviated survey}

\begin{tabular}{|c|c|}
\hline $\begin{array}{l}\text { Perceived } \\
\text { performance }\end{array}$ & $\begin{array}{l}\text { 1. Relative to your expectations, rate your degree of compliance with performance } \\
\text { goals regarding (Scale: } 1 \text { (strongly disagree) to } 5 \text { (strongly agree)): } \\
\text { (i) Sales volume } \\
\text { (ii) Return on assets }\end{array}$ \\
\hline \multirow[t]{2}{*}{$\begin{array}{l}\text { Exploitative } \\
\text { innovation }\end{array}$} & $\begin{array}{l}\text { 1. Please rate (Scale: (1), low and (5), high) the extent to which changes in } \\
\text { products/packaging design are: } \\
\text { (i) Important ... } \\
\text { (ii) A novelty for the market }\end{array}$ \\
\hline & $\begin{array}{l}\text { 2. Please rate (Scale: (1), low and (5), high) the extent to which improvements in } \\
\text { existing products are: } \\
\text { (i) Important ... } \\
\text { (ii) A novelty for the market }\end{array}$ \\
\hline \multirow[t]{2}{*}{$\begin{array}{l}\text { Exploratory } \\
\text { innovation }\end{array}$} & $\begin{array}{l}\text { 1. Please rate (Scale: (1), low and (5), high) the extent to which your innovations: } \\
\text { (i) Can change the market structure } \\
\text { (ii) Can create new markets } \\
\text { (iii) Can make existing products obsolete }\end{array}$ \\
\hline & $\begin{array}{l}\text { 2. Please rate (Scale: (1), low and (5), high) the extent to which new products } \\
\text { launched are: } \\
\text { (i) Important ... } \\
\text { (ii) A novelty for the market }\end{array}$ \\
\hline $\begin{array}{l}\text { Use of balanced } \\
\text { scorecard }\end{array}$ & $\begin{array}{l}\text { Is the balanced scorecard implemented in your firm? (yes/no) } \\
\text { 1. The balanced scorecard is used for results control (1) or continuous learning (5) } \\
\text { 2. The balanced scorecard is used to promote the efficiency of internal operations } \\
\text { (1) or for enhancing creative responses to environmental changes (5) } \\
\text { 3. Managers only discuss the balanced scorecard results face-to-face with their } \\
\text { executive team when there are deviations (1) or managers always debate the } \\
\text { reports of the balanced scorecard with their executive team (5) } \\
\text { 4. Information from the balanced scorecard is discussed face-to-face with team } \\
\text { managers rarely (1) or continuously (5) }\end{array}$ \\
\hline Development stage & 1. Year the company was founded \\
\hline $\begin{array}{l}\text { Adoption of } \\
\text { balanced scorecard }\end{array}$ & 1. Has your company adopted the balanced scorecard? [yes/no] \\
\hline $\begin{array}{l}\text { Implementation of } \\
\text { the balanced } \\
\text { scorecard }\end{array}$ & $\begin{array}{l}\text { 1. Please rate (Scale: (1), low and (5), high) the degree of implementation of the } \\
\text { balanced scorecard }\end{array}$ \\
\hline Family firm & $\begin{array}{l}\text { 1. Does a family group actively participate in organizational management and } \\
\text { control? [yes/no] }\end{array}$ \\
\hline \multirow[t]{3}{*}{ Strategy } & $\begin{array}{l}\text { 1. Has your firm performed any of the following...? } \\
\text { (i) Changes in product design and/or packaging: [yes/no] } \\
\text { (ii) New products launched: [yes/no] } \\
\text { (iii) New processes incorporated: [yes/no] }\end{array}$ \\
\hline & 2. Does your company have a staff training plan? [yes/no] \\
\hline & 3. Does your company perform promotional activities? [yes/no] \\
\hline Exports & 1. What percentage of company sales are exports? \\
\hline $\begin{array}{l}\text { Customer } \\
\text { concentration }\end{array}$ & $\begin{array}{l}\text { 1. Indicate the percentage of sales to the top } 3 \text { customers over the total sales of the } \\
\text { company }\end{array}$ \\
\hline Hostility & $\begin{array}{l}\text { 1. How many relevant competitors does your company have? } \\
\text { (i) We do not have competitors } \\
\text { (ii) Fewer than } 10 \text { companies } \\
\text { (iii) Between } 10 \text { and } 25 \text { companies } \\
\text { (iv) Over } 25 \text { companies }\end{array}$ \\
\hline$R \& D$ on sales & 1. Investment in R\&D with its own funding \\
\hline ISO 14000 & 1. Does your company have ISO 14000 Environmental certification? [yes/no] \\
\hline$R \& D$ collaboration & $\begin{array}{l}\text { 1. Does your company collaborate with other companies and institutions in terms } \\
\text { of innovation? (Scale: (1) low and (5) high) }\end{array}$ \\
\hline ICT & $\begin{array}{l}\text { 1. Indicate whether you use any of the following systems in the production process: } \\
\text { [yes/no] }\end{array}$ \\
\hline
\end{tabular}




\begin{tabular}{l|l}
\hline & $\begin{array}{l}\text { (i.) Numerical control machines } \\
\text { (ii) Computer-aided design } \\
\text { (iii) Robotics } \\
\text { (iv) A combination of the above by a central computer } \\
\text { (v) A local area network (LAN) in the manufacturing process }\end{array}$ \\
\hline R\&D employees & 1. Indicate the number of employees involved in R\&D activities \\
\hline
\end{tabular}




\section{Appendix B - Control variables}

\begin{tabular}{|c|c|}
\hline Implementation of BSC & $\begin{array}{l}\text { This variable measures the degree of implementation of BSC (see Appendix A). As } \\
\text { discussed by Garengo and Sharma (2014), firms that adopt BSC might implement } \\
\text { different versions of it, varying from simple to advanced. Issues of design (i.e., degree } \\
\text { of implementation) rather than use of BSC have been associated with innovation } \\
\text { outcomes and financial performance (Evans 2004). }\end{array}$ \\
\hline Family firm & $\begin{array}{l}\text { Family firm is a common control variable in SME literature. It is argued that family } \\
\text { ownership influences the use of managerial practices, determining distinctive } \\
\text { incentives, structures of authority, and accountability that affect firm outcomes (De } \\
\text { Massis et al. 2015). Family firm was captured with a dummy variable ( } 1 \text { if the } \\
\text { enterprise was a family firm; } 0 \text { otherwise) (see Appendix A). }\end{array}$ \\
\hline Strategy & $\begin{array}{l}\text { Previous literature suggests that different strategies might influence the outcome of } \\
\text { the use of managerial practices on innovation and financial performance (Branzei and } \\
\text { Vertinsky 2006). A factor score using five items asked respondents to rate the } \\
\text { importance of multiple strategic priorities (Gong and Ferreira 2014) } \\
\text { A). }\end{array}$ \\
\hline Exports & $\begin{array}{l}\text { Previous literature shows that innovation and export are complementary strategies for } \\
\text { the growth of SMEs (Golovko and Valentini 2011). Respondents were asked about the } \\
\text { percentage of exports over total sales (see Appendix A). }\end{array}$ \\
\hline Customer concentration & $\begin{array}{l}\text { Patatoukas (2012) found empirical evidence that customer concentration increases } \\
\text { predict efficiency gains in the form of reduced operating expenses and enhanced asset } \\
\text { utilization. Respondents were asked about the percentage of sales to the top } 3 \\
\text { customers over the total sales of the firm (see Appendix A). }\end{array}$ \\
\hline Hostility & $\begin{array}{l}\text { Researchers have argued that the performance implications of managerial practices } \\
\text { depend, to a great extent, on the environment in which the company operates. Hence, } \\
\text { hostile and volatile environments might diminish the effectiveness of BSC (Bisbe and } \\
\text { Malagueño 2012; Cosh et al. 2012). Hostility was evidenced by the intensity of } \\
\text { competition; assessed using a } 4 \text { point Likert scale capturing the number of relevant } \\
\text { competitors, from "We do not have competitors" to "Over } 25 \text { companies" (see } \\
\text { Appendix A). }\end{array}$ \\
\hline R\&D on sales & $\begin{array}{l}\text { It is expected that firms that invest more financial resources in R\&D, regardless of } \\
\text { their use of managerial practices, will be more innovative (Cosh et al. 2012). This was } \\
\text { measured as R\&D over sales (see Appendix A). }\end{array}$ \\
\hline ISO 14000 certification & $\begin{array}{l}\text { Cuerva et al. (2014) argue that the use of quality management standards by SMEs has } \\
\text { a positive effect on innovation outcomes. This variable was measured as a dummy } \\
\text { variable ( } 1 \text { if the enterprise was ISO } 14000 \text { certified; } 0 \text { otherwise) (see Appendix A). }\end{array}$ \\
\hline Sales & $\begin{array}{l}\text { This variable measures the effects of the previous year's financial performance. It was } \\
\text { measured as the log of sales in t. }\end{array}$ \\
\hline R\&D collaboration & $\begin{array}{l}\text { Previous literature shows that effects on SMEs' innovation performance might be } \\
\text { driven by collaborations rather than internal managerial practices (Cosh et al. 2012; } \\
\text { Eggers et al. 2014). Respondents were asked about the extent to which their firms } \\
\text { collaborate with others in terms of innovation (see Appendix A). }\end{array}$ \\
\hline Assets & $\begin{array}{l}\text { Book value of total assets in year } \mathrm{t} \text { is used to measure the size of the firm (Ittner et al. } \\
\text { 2003). }\end{array}$ \\
\hline Audited firm & $\begin{array}{l}\text { Previous literature has indicated that auditors might play an important intermediary } \\
\text { role in informing and implementing accounting innovations that have positive effects } \\
\text { on firm performance (Van Campenhout and Van Caneghem 2013). This variable is } \\
\text { measured with a dummy variable ( } 1 \text { if the firm was classified as an audited firm; } 0 \\
\text { otherwise). }\end{array}$ \\
\hline $\begin{array}{l}\text { Information and } \\
\text { communications } \\
\text { technology (ICT) }\end{array}$ & $\begin{array}{l}\text { First, it has been argued ICT leads firms to be better connected and to use more } \\
\text { efficient manufacturing processes. Secondly, ICT producing firms generate a large } \\
\text { volume of R\&D-based knowledge (Venturini 2015). A dummy variable captures ICT } \\
\text { ( } 1 \text { if the firm uses any of the proposed systems in the production process; } 0 \text { otherwise) } \\
\text { (See Appendix A). }\end{array}$ \\
\hline Intangibles to total assets & $\begin{array}{l}\text { Intangible resources have been pointed out as an important source of competitive } \\
\text { advantage among SMEs (Anderson and Eshima 2013). This variable was measured as } \\
\text { the book value of intangibles over book value of total assets in year t. }\end{array}$ \\
\hline
\end{tabular}

\footnotetext{
${ }^{12}$ Eigenvalue $=2.000 ; \%$ of variance $=40.01 ; \mathrm{KMO}=0.668$.
} 


\begin{tabular}{l|l}
\hline Cash to short liabilities & $\begin{array}{l}\text { This variable measures liquidity and short-term financial constraints for SMEs. } \\
\text { Excesses of cash have been associated with investment efficiency and profitability in } \\
\text { previous literature (Biddle et al. 2009). This variable was defined as the book value of } \\
\text { cash over the book value of short liabilities (Minnis 2011). }\end{array}$ \\
\hline R\&D employees & $\begin{array}{l}\text { It is expected that firms that invest more human resources in R\&D, regardless of their } \\
\text { use of managerial practices, will be more innovative. R\&D employees was measured } \\
\text { by the number of employees involved in R\&D activities, as shown in Appendix A. }\end{array}$ \\
\hline Short-term liabilities & $\begin{array}{l}\text { Previous results show that short-term loans are more common in SMEs with greater } \\
\text { financial strength, greater financial flexibility, and major growth options (García- } \\
\text { Teruel and Martínez-Solano 2007). This variable was captured by the book value of } \\
\text { short-term liabilities in thousands of Euros. }\end{array}$ \\
\hline Employees & $\begin{array}{l}\text { Number of employees is a commonly used control variable when assessing the } \\
\text { effectiveness of managerial practices (Bisbe and Malagueño 2012; Chang and Hughes } \\
\text { 2012). This is because the span of control is affected by the number of employees in a } \\
\text { firm. This variable was assessed by the number of employees in year t. }\end{array}$ \\
\hline
\end{tabular}




\section{References}

Anderson, B. S., \& Eshima, Y. (2013). The influence of firm age and intangible resources on the relationship between entrepreneurial orientation and firm growth among Japanese SMEs. Journal of Business Venturing, 28(3), 413-429. doi:10.1016/j.jbusvent.2011.10.001.

Ates, A., Garengo, P., Cocca, P., \& Bititci, U. (2013). The development of SME managerial practice for effective performance management. Journal of Small Business and Enterprise Development, 20(1), 28-54. doi:10.1108/14626001311298402.

Benner, M. J., \& Tushman, M. L. (2003). Exploitation, Exploration, and Process Management: The Productivity Dilemma Revisited. The Academy of Management Review, 28(2), 238-256. Retrieved from http://www.jstor.org/stable/30040711.

Biazzo, S., \& Garengo, P. (2012). Performance measurement with the balanced scorecard. A practical approach to implementation within SMEs. Berlin: Springer. ISBN 978-3-642-247613.

Biddle, G. C., Hilary, G., \& Verdi, R. S. (2009). How does financial reporting quality relate to investment efficiency?. Journal of Accounting and Economics, 48(2), 112-131. doi:10.1016/j.jacceco.2009.09.001.

Bisbe, J., \& Malagueño, R. (2009). The Choice of Interactive Control Systems under Different Innovation Management Modes. European Accounting Review, 18(2), 371-405. doi:10.1080/09638180902863803.

Bisbe, J., \& Malagueño, R. (2012). Using strategic performance measurement systems for strategy formulation: does it work in dynamic environments? Management Accounting Research, 23(4), 296-311. doi:10.1016/j.mar.2012.05.002.

Bititci, U., Garengo, P., Dorfler, V., \& Nudurupati, S. (2012). Performance measurement: challenges for tomorrow. International Journal of Management Reviews, 14(3), 305-327. doi:10.1111/j.1468-2370.2011.00318.x.

Bititci, U.S., Garengo, P., Ates, A., \& Nudurupati, S.S. (2015). Value of maturity models in performance measurement. International Journal of Production Research, 53(10), 3062-3085. doi:10.1080/00207543.2014.970709.

Branzei, O., \& Vertinsky, I. (2006). Strategic pathways to product innovation capabilities in SMEs. Journal of Business Venturing, 21(1), 75-105. doi:10.1016/j.jbusvent.2004.10.002.

Brinckmann, J., Grichnik, D., \& Kapsa, D. (2010). Should entrepreneurs plan or just storm the castle? A meta-analysis on contextual factors impacting the business planning-performance relationship in small firms. Journal of Business Venturing, 25(1), 24-40. doi:10.1016/j.jbusvent.2008.10.007.

Bromiley, P., \& Harris, J. D. (2014). A comparison of alternative measures of organizational aspirations. Strategic Management Journal, 35(3), 338-357. doi:10.1002/smj.2191.

Busco, C., \& Quattrone, P. (2015). Exploring how the balanced scorecard engages and unfolds: articulating the visual power of accounting inscriptions. Contemporary Accounting Research, 32(3), 1236-1262. doi:10.1111/1911-3846.12105.

Busenitz, L., \& Barney, J. (1997). Differences between entrepreneurs and managers in large organizations: biases and heuristics in strategic decision making. Journal of Business Venturing, 12(1), 9-30. doi:10.1016/S0883-9026(96)00003-1. 
Cardinal, L. B., Sitkin, S. B., \& Long, C. P. (2004). Balancing and rebalancing in the creation and evolution of organizational control. Organization Science, 15(4), 411-431. doi:10.1287/orsc.1040.0084.

Cardon, M. S., \& Stevens, C. E. (2004). Managing human resources in small organizations: What do we know? Human Resource Management Review, 14(3), 295-323. doi:10.1016/j.hrmr.2004.06.001.

Chang, Y-Y., \& Hughes, M. (2012). Drivers of innovation ambidexterity in small-to-mediumsized firms. European Management Journal, 30(1), 1-17. doi:10.1016/j.emj.2011.08.003.

Cheng, M. M., \& Humphreys, K. A. (2012). The Differential Improvement Effects of the Strategy Map and Scorecard Perspectives on Managers' Strategic Judgments. The Accounting Review, 87(3), 899-924. doi:10.2308/accr-10212.

Chowdhury, S. (2011). The moderating effects of customer driven complexity on the structure and growth relationship in young firms. Journal of Business Venturing, 26(3), 306-320. doi:10.1016/j.jbusvent.2009.10.001.

CIMA (2009). Research report: Management accounting tools for today and tomorrow. Chartered Institute of Management Accountants. ISBN: 978-1-85971-636-6.

Cooper, D. J., Ezzamel, M., \& Qu, S. Q. (2017). Popularizing a management accounting idea: The case of the balanced scorecard. Contemporary Accounting Research, 34(2), 991-1025. doi: 10.1111/1911-3846.12299.

Cosh, A. D., Fu, X., \& Hughes, A. (2012). Organization structure and innovation performance in different environment. Small Business Economics, 39(2), 1-17. doi:10.1007/s11187-0109304-5.

Covin, J. G., \& Slevin D. P. (1989) Strategic Management of Small Firms in Hostile and Benign Environments. Strategic Management Journal, 10(1), 75-87. doi:10.1002/smj.4250100107.

Cuerva, M. C., Triguero-Cano, Á., \& Córcoles, D. (2014). Drivers of green and non-green innovation: empirical evidence in Low-Tech SMEs. Journal of Cleaner Production, 68, 104113. doi:10.1016/j.jclepro.2013.10.049.

Danneels, E. 2002. The dynamics of product innovation and firm competencies. Strategic Management Journal, 23(12), 1095-1121. doi:10.1002/smj.275.

Davila, A., Foster, G., \& Li, M. (2009). Reasons for management control systems adoption: Insights from product development systems choice by early-stage entrepreneurial companies. Accounting, Organizations and Society, 34, 322-347. doi:10.1016/j.aos.2008.08.002.

Davila, T., Epstein, M., \& Shelton, R. (2012). Making innovation work: How to manage it, measure it, and profit from it. Upper Saddle River, NJ: Pearson Education. ISBN-13: 978-0-13-149786-3.

De Geuser, F., Mooraj, S., \& Oyon, D. (2009). Does the balanced scorecard add value? Empirical evidence on its effect on performance. European Accounting Review, 18(1), 93-122. doi:10.1080/09638180802481698.

De Massis, A., Frattini, F., Pizzurno, E., \& Cassia, L. (2015). Product innovation in family vs. non-family firms: An exploratory analysis. Journal of Small Business Management, 53(1), 136. doi:10.1111/jsbm.12068.

Dillman, D. A. (2000). Mail and internet surveys: The tailored design method (2 ed). NewYork: Wiley. ISBN-13: 978-0-470-03856-7. 
Ebben J. J., \& Johnson, A. C. (2005). Efficiency, Flexibility, or Both? Evidence linking strategy to performance in small firms. Strategic Management Journal, 26(13), 1249-1259. doi:10.1002/smj.503.

Eggers, F., Kraus, S., \& Covin, J. G. (2014). Traveling into unexplored territory: radical innovativeness and the role of networking, customers, and technologically turbulent environments. Industrial Marketing Management, 43(8), 1385-1393. doi:10.1016/j.indmarman.2014.08.006.

Eisenhardt, K. M., Furr, N. R., \& Bingham, C. B. (2010). Microfoundations of performance: balancing efficiency and flexibility in dynamic environments. Organization Science, 21(6), 1263-1273. doi:10.1287/orsc.1100.0564.

Evans, J. R. (2004). An Exploratory Study of Performance Measurement Systems and Relationships with Performance Results. Journal of Operations Management, 22(3), 219-232. doi:10.1016/j.jom.2004.01.002.

Evans, W. R., \& Davis, W. D. (2005). High-performance work systems and organizational performance: The mediating role of internal social structure. Journal of Management, 31(5), 758-775. doi:10.1177/0149206305279370.

Fernandes, K. J., Rajab, V., \& Whalley, A. (2006). Lessons from implementing the balanced scorecard in a small and medium size manufacturing organization. Technovation, 26(5-6), 623634. doi:10.1016/j.technovation.2005.03.006.

Freel, M. S. (2000). Strategy and Structure in Innovative Manufacturing SMEs: The Case of an English Region. Small Business Economics, 15(1), 27-45. doi:10.1023/A:1012087912632.

García-Teruel, P. J., \& Martínez-Solano, P. (2007). Short-term debt in Spanish SMEs. International Small Business Journal, 25(6), 579-602. doi:10.1177/0266242607082523.

Garengo, P., \& Bititci, U. (2007). Towards a contingency approach to performance measurement: an empirical study in Scottish SMEs. International Journal of Operations \& Production Management, 27(8), 802-825. doi:10.1108/01443570710763787.

Garengo, P., \& Sharma, M. K. (2014). Performance measurement system contingency factors: a cross analysis of Italian and Indian SMEs. Production Planning \& Control, 25(3), 220-240. doi:10.1080/09537287.2012.663104.

Garengo, P., Biazzo, S., \& Bititci, U. S. (2005). Performance measurement systems in SMEs: a review for a research agenda. International Journal of Management Reviews, 7(1), 25-47. doi:10.1111/j.1468-2370.2005.00105.x.

Glaser, L., Fourné, S., \& Elfring, T. (2015). Achieving strategic renewal: The multi-level influences of top and middle managers' boundary-spanning. Small Business Economics, 45(2), 305-327. doi:10.1007/s11187-015-9633-5.

Golovko, E., \& Valentini, G. (2011). Exploring the complementarity between innovation and export for SMEs' growth. Journal of International Business Studies, 362-380. doi:10.1057/jibs.2011.2.

Gong, M. Z., \& Ferreira, A. (2014). Does consistency in management control systems design choices influence firm performance? An empirical analysis. Accounting and Business Research, 44(5), 497-522. doi:10.1080/00014788.2014.901164.

Grafton, J., Lillis, A. M., \& Widener S. K. (2010). The role of performance measurement and evaluation in building organizational capabilities and performance. Accounting, Organizations and Society, 35(7), 689-706. doi:10.1016/j.aos.2010.07.004. 
Gumbus, A., \& Lussier, R. N. (2006). Entrepreneurs Use a Balanced Scorecard to Translate Strategy into Performance Measures. Journal of Small Business Management, 44(3), 407-425. doi:10.1111/j.1540-627X.2006.00179.x.

Hervas-Oliver, J-L., Sempere-Ripoll, F., \& Boronat-Moll, C. (2016). Does management innovation pay-off in SMEs? Empirical evidence for Spanish SMEs. Small Business Economics, 47(2), 507-533. doi:10.1007/s11187-016-9733-x.

Hill, C. W. L., \& Rothaermel, F. T. (2003). The Performance of Incumbent Firms in the Face of Radical Technological Innovation. The Academy of Management Review, 28(2), 257-274. Retrieved from http://www.jstor.org/stable/30040712.

Hoque, Z. (2003). Total quality management and the balanced scorecard approach: a critical analysis of their potential relationships and directions for research. Critical Perspectives on Accounting, 14(5), 553-566. doi:10.1016/S1045-2354(02)00160-0.

Hudson-Smith, M., \& Smith, D. (2007). Implementing strategically aligned performance measurement in small firms. International Journal of Production Economics, 106(2), 393-408. doi:10.1016/j.ijpe.2006.07.011.

Ittner, C. D., Larcker, D. F., \& Randall, T. (2003). Performance implications of strategic performance measurement in financial services firms. Accounting, Organizations and Society, 28(7-8), 715-741. doi:10.1016/S0361-3682(03)00033-3.

Jänkälä, S., \& Silvola, H. (2012). Lagging Effects of the Use of Activity-Based Costing on the Financial Performance of Small Firms. Journal of Small Business Management, 50(3), 498523. doi:10.1111/j.1540-627X.2012.00364.x.

Jansen, J. J. P., Van den Bosch, F. A. J. \& Volberda, H. W. (2006). Exploratory innovation, exploitative innovation, and performance: Effects of organizational antecedents and environmental moderators. Management Science, 52, 1661-1674. doi:10.1287/mnsc. 1060.0576 .

Jones, O., \& Macpherson, A. (2006). Inter-organisational learning and strategic renewal in SMEs: extending the 4I framework. Long Range Planning, 39, 155-175. doi:10.1016/j.lrp.2005.02.012.

Kallunki, J. P., \& Silvola, H. (2008). The effect of organizational life cycle stage on the use of activity-based costing. Management Accounting Research, 19(1), 62-79. doi:10.1016/j.mar.2007.08.002.

Kaplan, R. S., \& Norton, D. P. (1996). The Balanced Scorecard. Harvard Business School Press, Boston.

Kaynak, E. \& Kara, A. (2004). Market orientation and organizational performance: A comparison of industrial versus consumer companies in Mainland China using market orientation scale MARKOR. Industrial Marketing Management, 33(8), 743-753. doi:10.1016/j.indmarman.2004.01.003.

Koufteros, X., Verghese, A., \& Lucianetti, L. (2014). The effect of performance measurement systems on firm performance: A cross-sectional and a longitudinal study. Journal of Operations Management, 32(6), 313-336. doi:10.1016/j.jom.2014.06.003.

Koskinen, K. U., \& Vanharanta, H. (2002). The role of tacit knowledge in innovation processes of small technology companies. International Journal of Production Economics, 80(1), 57-64. doi:10.1016/S0925-5273(02)00243-8. 
Leonard-Barton, D. (1992). Core capabilities and core rigidities: A paradox in managing new product development. Strategic Management Journal, 13(S1), 111-125. doi: 10.1002/smj.4250131009.

Lin, Z. (J.), Yang, H., \& Demirkan. I. (2007). The performance consequences of ambidexterity in strategic alliance formations: Empirical investigation and computational theorizing. Management Science, 53(10), 1645-1658. doi:10.1287/mnsc.1070.0712.

López O. L., \& Hiebl, M. R. W. (2015). Management accounting in small and medium-sized enterprises: current knowledge and avenues for further research. Journal of Management Accounting Research, 27(1), 81-119. doi:10.2308/jmar-50915.

Lubatkin, M. H., Simsek, Z., Ling, Y., \& Veiga, J. F. (2006). Ambidexterity and performance in small- to medium-sized firms: The pivotal role of TMT behavioral integration. Journal of Management, 32(5), 1-27. doi:10.1177/0149206306290712.

Malmi, T. \& Brown, D.A., (2008). Management control systems as a package-Opportunities, challenges and research directions. Management Accounting Research, 19, 287-300. doi:10.1016/j.mar.2008.09.003.

McAdam, R. (2000). Quality models in an SME context a critical perspective using a grounded approach. The International Journal of Quality \& Reliability Management, 17(3), 305-323. doi:10.1108/02656710010306166.

McAdam, R., Antony, J. Kumar, M., \& Hazlett, S. A. (2014). Absorbing New Knowledge in Small and Medium-sized Enterprises: A Multiple Case Analysis of Six Sigma. International Small Business Journal, 32(1), 81-109. doi:10.1177/0266242611406945.

McCarthy, I. P., \& Gordon, B. R. (2011). Achieving contextual ambidexterity in R\&D organizations: a management control system approach. $R \& D$ Management, 41(3), 240-258. doi:10.1111/j.1467-9310.2011.00642.x.

Medori, D., \& Steeple, D. (2000). A framework for auditing and enhancing performance measurement systems. International Journal of Operations \& Production Management, 20(5), 520-533. doi: 10.1108/01443570010318896.

Micheli, P., \& Manzoni, J. F. (2010). Strategic performance measurement systems: benefits, limitations and paradoxes. Long Range Planning, 43(4), 465-476. doi:10.1016/j.lrp.2009.12.004.

Minnis, M. (2011). The value of financial statement verification in debt financing: Evidence from private U.S. firms. Journal of Accounting Research, 49, 457-506. doi:10.1111/j.1475679X.2011.00411.x

Nickerson, J. A., \& Zenger. T. R. (2002). Being efficiently fickle: A dynamic theory of organizational choice. Organization Science, 13(5), 547-566. doi:10.1287/orsc.13.5.547.7815.

Nørreklit, H. (2000). The balance on the balanced scorecard critical analysis of some of its assumptions. Management Accounting Research, 11(1), 65-88. doi:10.1006/mare.1999.0121.

Nunnally, J. C. (1978). Psychometric theory. New York: McGraw Hill Book Company.

Patatoukas, P. N. (2011). Customer-base concentration: Implications for firm performance and capital markets. The Accounting Review, 87(2), 363-392. doi: 10.2308/accr-10198.

Patel, P. C. (2011). Role of manufacturing flexibility in managing duality of formalization and environmental uncertainty in emerging firms. Journal of Operations Management, 29(1), 143162. doi:10.1016/j.jom.2010.07.007. 
Pavlov, A., \& Bourne, M. (2011). Explaining the effects of performance measurement on performance. International Journal of Operations \& Production Management, 31(1), 101-122. doi:10.1108/01443571111098762.

Podsakoff, P.M., MacKenzie, S.B., Lee, J.-Y., \& Podsakoff, N.P. (2003). Common method biases in behavioural research: a critical review of the literature and recommended remedies. Journal of Applied Psychology, 88(5), 879-903. doi:10.1037/0021-9010.88.5.879.

Rigby, D., \& Bilodeau, B. (2015). Management Tools \& Trends 2015. Bain \& Company. http://www.bain.com/publications/articles/management-tools-and-trends-2015.aspx. Accessed 4 May 2017.

Rosenbusch, N., Brinckmann, J., \& Bausch, A. (2011). Is innovation always beneficial? A metaanalysis of the relationship between innovation and performance in SMEs. Journal of Business Venturing, 26(4), 441-457. doi:10.1016/j.jbusvent.2009.12.002.

Schjoedt, L. \& Bird, B. (2014). Control variables: use, misuse, and recommended use. In A. Carsrud \& M. E. Brännback (Eds.), Handbook of Research Methods and Applications in Entrepreneurship and Small Business (pp. 136-155). Northampton, MA: Edward Elgar. ISBN:978-0-85793-504-5.

Spithoven, A., Vanhaverbeke, W., \& Roijakkers, N. (2013). Open innovation practices in SMEs and large enterprises. Small Business Economics, 41(3), 537-562. doi:10.1007/s11187-0129453-9.

Srećković, M. (2017). The performance effect of network and managerial capabilities of entrepreneurial firms. Small Business Economics, 1-18. doi:10.1007/s11187-017-9896-0.

Taylor, A., \& Taylor, M. (2014). Factors influencing effective implementation of performance measurement systems in small and medium-sized and large firms: a perspective from Contingency Theory. International Journal of Production Research, 52(3), 847-866. doi:10.1080/00207543.2013.842023.

Tuomela, T. S. (2005). The interplay of different levers of control: A case study of introducing a new performance measurement system. Management Accounting Research, 16(3), 293-320. doi:10.1016/j.mar.2005.06.003.

Van Campenhout, G., \& Van Caneghem, T. (2013). How did the notional interest deduction affect Belgian SMEs' capital structure?. Small Business Economics, 40, 1-23. doi:10.1007/s11187011-9364-1.

Venturini, F, (2015). The modern drivers of productivity. Research Policy, 44(2), 357-369. doi: 10.1016/j.respol.2014.10.011

Vermeulen, P. A. M. (2005). Uncovering barriers to complex incremental product innovation in small and medium-sized financial services firms. Journal of Small Business Management, 43(4), 432-452. doi:10.1111/j.1540-627X.2005.00146.x.

Volery, T., Mueller, S., \& Vonsiemens, B. (2015). Entrepreneur ambidexterity: A study of entrepreneur behaviours and competencies in growth-oriented small and medium-sized enterprises. International Small Business Journal, 33(2), 109-129. doi:10.1177/0266242613484777.

Voss, U., \& Brettel, M. (2014). The Effectiveness of Management Control in Small Firms: Perspectives from Resource Dependence Theory. Journal of Small Business Management 52(3), 569-587. doi:10.1111/jsbm.12050. 
Wijbenga, F. H., Postma, T. J. B. M., \& Stratling, R. (2007). The influence of the venture capitalist's governance activities on the entrepreneurial firm's control systems and performance. Entrepreneurship: Theory and Practice, 31(2), 257-277. doi:10.1111/j.15406520.2007.00172.x.

Wouters, M., \& Wilderom, C. (2008). Developing performance-measurement systems as enabling formalization: A longitudinal field study of a logistics department. Accounting, Organizations and Society, 33(4), 488-516. doi:10.1016/j.aos.2007.05.002. 
Table 1

Descriptive statistics of the sample $(n=201)$

\begin{tabular}{lcccc}
\hline & Mean & Std. Dev. & Minimum & Maximum \\
\hline Number of shareholders & 2.95 & 3.47 & 1 & 40 \\
Number of patents & 3.35 & 21.09 & 0 & 200 \\
Managers with higher education (\%) & 45.42 & 41.37 & 0 & 100 \\
Number of employees & 32.75 & 36.94 & 10 & 230 \\
Foreign equity (\%) & 3.66 & 16.87 & 0 & 100 \\
\hline & Number & Percentage & & \\
\hline Audited firm & 73 & $36.32 \%$ & & \\
Business unit & 31 & $15.42 \%$ & & \\
Family firm & 152 & $75.62 \%$ & & \\
\hline
\end{tabular}




\section{Table 2}

Reliability and validity analysis $(n=201)$

\begin{tabular}{|c|c|c|c|c|c|c|}
\hline Constructs & Items & Loadings & $\begin{array}{l}\text { Variance } \\
\text { explained }\end{array}$ & $\begin{array}{c}\text { Cronbach } \\
\alpha\end{array}$ & KMO & Bartlett \\
\hline \multirow{2}{*}{$\begin{array}{l}\text { Perceived } \\
\text { performance }\end{array}$} & Sales & 0.890 & 0.791 & 0.735 & 0.500 & 0.000 \\
\hline & Return on assets & 0.890 & & & & \\
\hline \multirow{4}{*}{$\begin{array}{l}\text { Exploitative } \\
\text { innovation }\end{array}$} & Changes in product design, importance & 0.860 & 0.742 & 0.883 & 0.631 & 0.000 \\
\hline & Changes in product design, novelty & 0.884 & & & & \\
\hline & $\begin{array}{l}\text { Improvements in existing products, } \\
\text { importance }\end{array}$ & 0.831 & & & & \\
\hline & Improvements in existing products, novelty & 0.870 & & & & \\
\hline \multirow{5}{*}{$\begin{array}{l}\text { Exploratory } \\
\text { innovation }\end{array}$} & New products, importance & 0.721 & 0.527 & 0.756 & 0.633 & 0.000 \\
\hline & New products, novelty & 0.724 & & & & \\
\hline & Innovation changes the market structure & 0.762 & & & & \\
\hline & Innovation can create new markets & 0.712 & & & & \\
\hline & $\begin{array}{l}\text { Innovation can make existing products } \\
\text { obsolete }\end{array}$ & 0.709 & & & & \\
\hline \multirow{4}{*}{ Use of BSC } & BSC for continuous learning & 0.944 & 0.919 & 0.970 & 0.852 & 0.000 \\
\hline & BSC for creative responses & 0.953 & & & & \\
\hline & BSC for continuous face-to-face discussion & 0.965 & & & & \\
\hline & BSC for permanent attention & 0.971 & & & & \\
\hline
\end{tabular}

Loadings of indicators on latent constructs of 0.7 or above indicate good indicator reliability.

Alpha: Cronbach's $\alpha, 0.7$ or above indicates good indicator reliability.

KMO of 0.5 or above and Bartlett's test of 0.00 or below indicate good indicator unidimensionality. 
Table 3

Descriptive statistics for research variables

\begin{tabular}{|c|c|c|c|c|c|}
\hline \multirow[b]{2}{*}{ Items } & \multicolumn{3}{|c|}{$\begin{array}{l}\text { Full sample } \\
\quad(n=201)\end{array}$} & \multirow{2}{*}{$\begin{array}{c}\begin{array}{c}\text { BSC } \\
\text { adopters } \\
(n=70)\end{array} \\
\text { Mean }\end{array}$} & \multirow{2}{*}{$\begin{array}{c}\begin{array}{c}\text { BSC non- } \\
\text { adopters } \\
(n=131)\end{array} \\
\text { Mean }\end{array}$} \\
\hline & Mean & Std. dev. & Min-Max & & \\
\hline \multicolumn{6}{|l|}{ Financial performance } \\
\hline Sales per employee year $t$ & 223.63 & 393.61 & $30.18-4,617.47$ & 261.20 & 202.38 \\
\hline Sales & 3.49 & 0.91 & $1-5$ & 3.41 & 3.53 \\
\hline Return on assets & 3.20 & 0.97 & $1-5$ & 3.19 & 3.21 \\
\hline \multicolumn{6}{|l|}{ Exploitative innovation } \\
\hline Changes in product design, importance & 2.49 & 1.75 & $0-5$ & 2.67 & 2.40 \\
\hline Changes in product design, novelty & 2.38 & 1.77 & $0-5$ & 2.63 & 2.24 \\
\hline Improvements in existing products, importance & 2.76 & 1.69 & $0-5$ & 2.93 & 2.67 \\
\hline Improvements in existing products, novelty & 2.37 & 1.59 & $0-5$ & 2.67 & 2.21 \\
\hline \multicolumn{6}{|l|}{ Exploratory innovation } \\
\hline New products, importance & 2.43 & 1.80 & $0-5$ & 2.69 & 2.30 \\
\hline New products, novelty & 2.28 & 1.80 & $0-5$ & 2.61 & 2.11 \\
\hline Innovation changes the market structure & 2.26 & 0.99 & $1-5$ & 2.27 & 2.25 \\
\hline Innovation can create new markets & 2.50 & 1.05 & $1-5$ & 2.64 & 2.43 \\
\hline Innovation can make existing products obsolete & 2.11 & 0.96 & $1-5$ & 2.19 & 2.08 \\
\hline \multicolumn{6}{|l|}{ Use of $B S C$} \\
\hline BSC for continuous learning & 1.07 & 1.64 & $0-5$ & 3.07 & 0.00 \\
\hline BSC for creative responses & 0.98 & 1.58 & $0-5$ & 2.81 & 0.00 \\
\hline BSC for continuous face-to-face discussion & 1.19 & 1.83 & $0-5$ & 3.43 & 0.00 \\
\hline BSC for permanent attention & 1.12 & 1.76 & $0-5$ & 3.23 & 0.00 \\
\hline \multicolumn{6}{|l|}{ Development stage } \\
\hline Firm age & 36.31 & 28.37 & $2-111$ & 32.60 & 38.29 \\
\hline \multicolumn{6}{|l|}{ Control variables } \\
\hline Implementation of BSC & 1.71 & 1.28 & $0-5$ & 3.09 & 0.00 \\
\hline Family firm & 0.76 & 0.43 & $0-1$ & 0.77 & 0.75 \\
\hline Strategy & 0.73 & 0.30 & $0-1$ & 0.64 & 0.81 \\
\hline Exports & 16.23 & 23.53 & $0-100$ & 17.89 & 15.34 \\
\hline Customer concentration & 41.20 & 25.83 & $0-100$ & 37.31 & 43.28 \\
\hline Hostility & 2.05 & 0.79 & $1-3$ & 1.96 & 2.11 \\
\hline R\&D on Sales & 0.02 & 0.12 & $0-1.55$ & 0.02 & 0.02 \\
\hline ISO 14000 & 0.12 & 0.33 & $0-1$ & 0.16 & 0.10 \\
\hline Sales & $8,946.11$ & $21,635.45$ & $25.51-211,186.76$ & $10,051.77$ & $8,340.63$ \\
\hline R\&D collaboration & 1.98 & 1.05 & $1-5$ & 2.01 & 1.97 \\
\hline Assets & $8,215.16$ & $17,164.14$ & $19.87-136,548.00$ & $7,552.74$ & $8,577.91$ \\
\hline Audited firm & 0.36 & 0.48 & $0-1$ & 0.36 & 0.37 \\
\hline ICT & 0.45 & 0.50 & $0-1$ & 0.50 & 0.43 \\
\hline Intangibles to Total Assets & 0.02 & 0.05 & $0.00-0.68$ & 0.02 & 0.01 \\
\hline Cash to Short Liabilities & 2.20 & 2.97 & $0.19-30.93$ & 2.32 & 2.14 \\
\hline R\&D employees & 1.58 & 2.78 & $0-25$ & 2.63 & 1.01 \\
\hline Short-term liabilities & $1,294.70$ & $3,160.89$ & $0.32-22,866.21$ & $1,384.17$ & $1,245.53$ \\
\hline Employees & 32.75 & 36.94 & $10-230$ & 35.20 & 31.32 \\
\hline
\end{tabular}


Table 4

Multitrait matrix

\begin{tabular}{|c|c|c|c|c|c|c|c|c|c|c|c|c|}
\hline & 1 & 2 & 3 & 4 & 5 & 6 & 7 & 8 & 9 & 10 & 11 & 12 \\
\hline 1. Sales per employee & 1.000 & & & & & & & & & & & \\
\hline 2. Perceived performance & $0.259 * * *$ & 1.000 & & & & & & & & & & \\
\hline 3. Exploitative innovation & 0.055 & $0.188 * * *$ & 1.000 & & & & & & & & & \\
\hline 4. Exploratory innovation & 0.070 & $0.145^{*}$ & $0.676^{* * *}$ & 1.000 & & & & & & & & \\
\hline 5. Use of BSC & 0.098 & -0.021 & $0.165 * *$ & $0.168 * *$ & 1.000 & & & & & & & \\
\hline 6. Development stage & 0.063 & -0.033 & 0.114 & 0.054 & -0.084 & 1.000 & & & & & & \\
\hline 7. Implementation of BSC & 0.049 & -0.009 & $0.118^{*}$ & $0.161 * *$ & $0.759 * * *$ & -0.047 & 1.000 & & & & & \\
\hline 8. Family firm & 0.068 & 0.075 & 0.105 & $0.119 *$ & 0.021 & 0.089 & 0.026 & 1.000 & & & & \\
\hline 9. Strategy & 0.116 & $0.204 * * *$ & $0.542 * * *$ & $0.551 * * *$ & $0.253 * * *$ & 0.081 & $0.210 * * *$ & $0.208 * * *$ & 1.000 & & & \\
\hline 10. Exports & $0.150 * *$ & $0.117 *$ & 0.041 & 0.060 & 0.069 & -0.031 & 0.079 & -0.054 & $0.139 * *$ & 1.000 & & \\
\hline 11. Customer concentration & 0.017 & $0.126^{*}$ & 0.014 & 0.002 & -0.047 & $-0.121 *$ & -0.054 & -0.090 & -0.071 & 0.081 & 1.000 & \\
\hline 12. Hostility & 0.009 & -0.082 & -0.051 & -0.080 & -0.114 & 0.098 & -0.102 & -0.048 & -0.071 & -0.011 & -0.096 & 1.000 \\
\hline 13. R\&D on Sales & $0.179 * *$ & 0.041 & 0.107 & $0.163 * *$ & -0.009 & -0.115 & -0.068 & $-0.141 * *$ & 0.076 & 0.000 & 0.054 & -0.064 \\
\hline 14. ISO 14000 & $0.301 * * *$ & 0.113 & -0.038 & 0.102 & 0.090 & -0.002 & 0.083 & -0.041 & 0.092 & $0.266 * * *$ & $0.183 * * *$ & -0.064 \\
\hline 15. Sales $(\log )$ & $0.409 * * *$ & $0.241 * * *$ & 0.004 & 0.116 & 0.095 & 0.091 & $0.119^{*}$ & $0.169 * *$ & $0.192 * * *$ & $0.360 * * *$ & $0.139 *$ & -0.027 \\
\hline 16. $R \& D$ collaboration & 0.040 & 0.111 & $0.288 * * *$ & $0.424 * * *$ & 0.028 & 0.096 & 0.038 & 0.113 & $0.259 * * *$ & $0.125 *$ & $0.065^{*}$ & 0.031 \\
\hline 17. Assets & $0.456^{* * *}$ & $0.167 * *$ & 0.080 & 0.115 & 0.006 & $0.200 * * *$ & 0.006 & $0.139 *$ & $0.157 * *$ & $0.253 * * *$ & -0.007 & -0.049 \\
\hline 18. Audited firm & $0.312 * * *$ & $0.303 * * *$ & 0.047 & $0.136^{*}$ & 0.022 & -0.010 & 0.033 & 0.067 & $0.190 * * *$ & 0.100 & 0.065 & $-0.117 *$ \\
\hline 19. ICT & 0.017 & 0.012 & $0.179 * *$ & $0.264 * * *$ & 0.056 & 0.037 & 0.104 & 0.074 & $0.210 * * *$ & -0.022 & -0.094 & 0.076 \\
\hline 20. Intangibles to Total Assets & -0.052 & $-0.173 * *$ & $0.148 * *$ & $0.145^{*}$ & 0.003 & -0.104 & 0.002 & -0.096 & -0.114 & -0.014 & -0.062 & -0.083 \\
\hline 21. Cash to Short Liabilities & -0.052 & $-0.156^{* *}$ & -0.107 & -0.140 & 0.030 & 0.093 & 0.005 & -0.091 & -0.007 & -0.082 & -0.094 & 0.064 \\
\hline 22. R\&D employees & $0.212 * * *$ & 0.088 & 0.094 & $0.216^{* * *}$ & $0.301 * * *$ & -0.111 & $0.228 * * *$ & -0.004 & $0.284 * * *$ & $0.217 * * *$ & -0.053 & $-0.130 *$ \\
\hline 23. Short-term liabilities & $0.299 * * *$ & 0.028 & 0.043 & 0.065 & 0.071 & 0.098 & 0.071 & 0.048 & 0.112 & $0.171 * *$ & 0.100 & -0.061 \\
\hline \multirow[t]{2}{*}{ 24. Employees } & 0.090 & $0.199 * * *$ & 0.087 & $0.147 * *$ & 0.058 & 0.102 & 0.038 & $0.161 * *$ & $0.236 * * *$ & 0.115 & 0.104 & $-0.181 * *$ \\
\hline & 13 & 14 & 15 & 16 & 17 & 18 & 19 & 20 & 21 & 22 & 23 & 24 \\
\hline 13. R\&D on Sales & 1.000 & & & & & & & & & & & \\
\hline 14. ISO 14000 & $0.162 * *$ & 1.000 & & & & & & & & & & \\
\hline 15. Sales $(\log )$ & 0.026 & $0.249 * * *$ & 1.000 & & & & & & & & & \\
\hline 16. $\mathrm{R} \& \mathrm{D}$ collaboration & -0.032 & $0.166^{* *}$ & $0.183^{* *}$ & 1.000 & & & & & & & & \\
\hline 17. Assets & -0.029 & $0.191 * * *$ & $0.676^{* * *}$ & 0.103 & 1.000 & & & & & & & \\
\hline 18. Audited firm & 0.050 & $0.264 * * *$ & $0.681 * * *$ & $0.169 * *$ & $0.436^{* * *}$ & 1.000 & & & & & & \\
\hline 19. ICT & -0.063 & 0.004 & $0.190 * * *$ & $0.204 * * *$ & 0.043 & $0.124^{*}$ & 1.000 & & & & & \\
\hline 20. Intangibles to Total Assets & 0.057 & -0.022 & -0.082 & 0.064 & -0.046 & -0.053 & -0.022 & 1.000 & & & & \\
\hline 21. Cash to Short Liabilities & -0.022 & -0.062 & -0.098 & -0.032 & -0.007 & -0.110 & 0.018 & -0.048 & 1.000 & & & \\
\hline 22. R\&D employees & $0.118^{*}$ & $0.145^{* *}$ & $0.326^{* * *}$ & $0.168 * *$ & $0.196^{* * *}$ & $0.280 * * *$ & $0.173 * *$ & 0.006 & -0.031 & 1.000 & & \\
\hline 23. Short-term liabilities & -0.067 & $0.126^{*}$ & $0.453 * * *$ & 0.065 & $0.645 * * *$ & $0.291 * * *$ & 0.020 & -0.036 & $-0.125^{*}$ & 0.085 & 1.000 & \\
\hline 24. Employees & -0.055 & $0.300 * * *$ & $0.614 * * *$ & $0.159 * *$ & $0.603 * * *$ & $0.527 * * *$ & $0.125^{*}$ & -0.046 & -0.084 & $0.237 * * *$ & $0.353 * * *$ & 1.000 \\
\hline
\end{tabular}

$* \mathrm{p}<0.10$ (two-tailed); $* * \mathrm{p}<0.05$ (two-tailed); $* * * \mathrm{p}<0.01$ (two-tailed) 
Table 5

Regression results for hypotheses H1

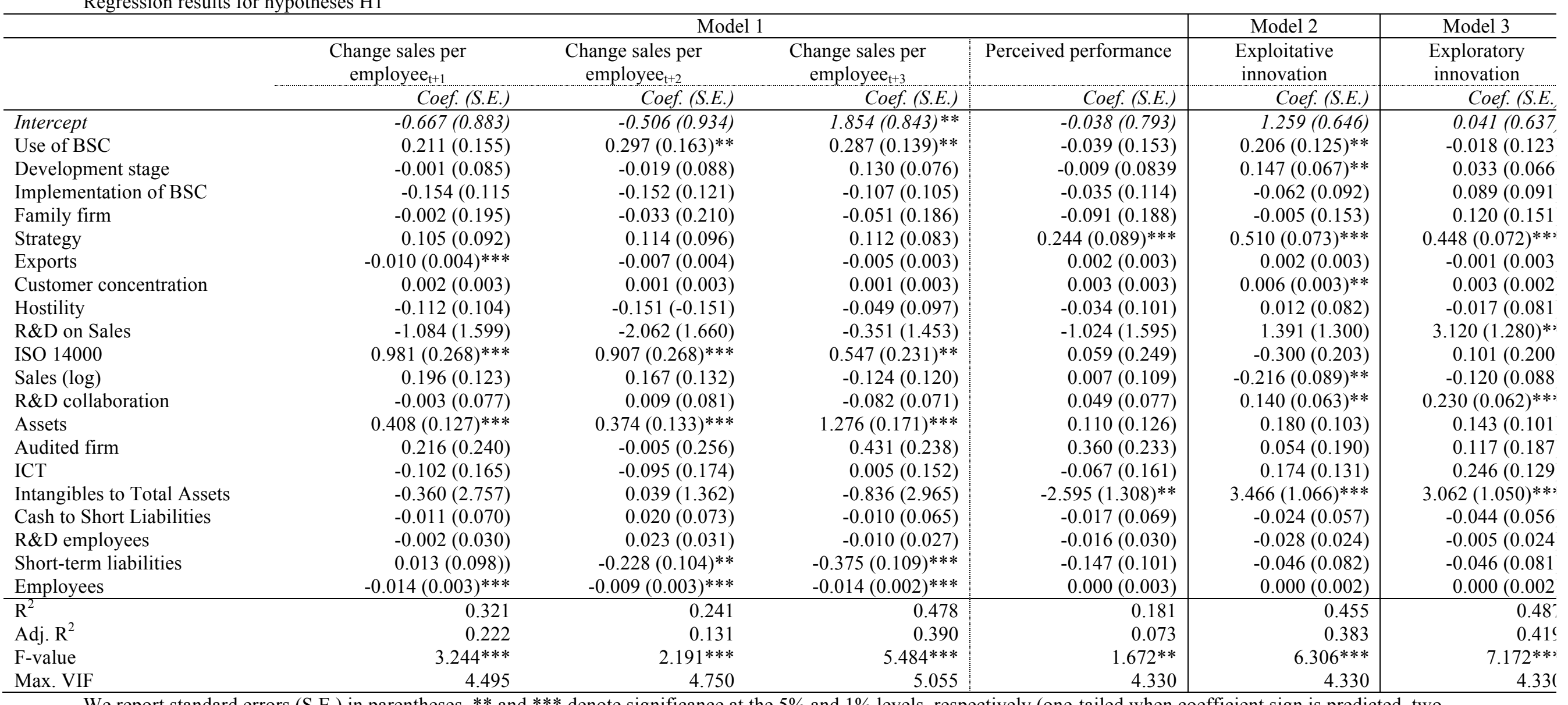

We report standard errors (S.E.) in parentheses. $* *$ and $* * *$ denote significance at the $5 \%$ and $1 \%$ levels, respectively (one-tailed when coefficient sign is predicted, twotailed otherwise). 
Table 6

Regression results for hypotheses H2

\begin{tabular}{|c|c|c|c|c|c|c|}
\hline & \multicolumn{4}{|c|}{ Model 4} & \multirow{2}{*}{$\begin{array}{c}\text { Model } 5 \\
\text { Exploitative } \\
\text { innovation }\end{array}$} & \multirow{2}{*}{$\begin{array}{c}\text { Model } 6 \\
\text { Exploratory } \\
\text { innovation }\end{array}$} \\
\hline & $\begin{array}{c}\text { Change sales per } \\
\text { employee }_{t+1}\end{array}$ & $\begin{array}{l}\text { Change sales per } \\
\text { employee }+2\end{array}$ & $\begin{array}{c}\text { Change sales per } \\
\text { employee }\end{array}$ & $\begin{array}{c}\text { Perceived } \\
\text { performance }\end{array}$ & & \\
\hline & Coef. (S.E.) & Coef. (S.E.) & Coef. (S.E.) & Coef. (S.E.) & Coef. (S.E.) & Coef. (S.E.) \\
\hline Intercept & $-0.198(0.856)$ & $-0.027(0.897)$ & $2.102(0.805) * *$ & $0.091(0.796)$ & $1.296(0.652)^{* *}$ & $0.009(0.642)$ \\
\hline Use of BSC & $0.269(0.149)^{* *}$ & $0.358(0.156)^{* *}$ & $0.336(0.133)^{* * *}$ & $-0.015(0.153)$ & $0.213(0.126)^{* *}$ & $-0.024(0.124)$ \\
\hline Development stage & $0.047(0.083)$ & $0.045(0.085)$ & $0.174(0.074)^{* *}$ & $0.018(0.085)$ & $0.154(0.069)^{* *}$ & $0.027(0.068)$ \\
\hline Use of BSC * Development stage & $0.329(0.091)^{* * *}$ & $0.367(0.094)^{* * *}$ & $0.289(0.079)^{* * *}$ & $0.133(0.093)$ & $0.038(0.077)$ & $-0.033(0.075)$ \\
\hline Implementation of BSC & $-0.190(0.111)$ & $-0.191(0.116)$ & $-0.148(0.101)$ & $-0.048(0.113)$ & $-0.066(0.093)$ & $0.093(0.092)$ \\
\hline Family firm & $-0.013(0.187)$ & $-0.035(0.200)$ & $-0.043(0.177)$ & $-0.097(0.187)$ & $-0.007(0.153)$ & $0.122(0.151)$ \\
\hline Strategy & $0.179(0.090)^{* *}$ & $0.195(0.094)^{* *}$ & $0.186(0.081)^{* *}$ & $0.270(0.091)^{* * *}$ & $0.517(0.075)^{* * *}$ & $0.442(0.073) * * *$ \\
\hline Exports & $-0.010(0.003)^{* * *}$ & $-0.007(0.004)$ & $-0.006(0.003)$ & $0.001(0.003)$ & $0.002(0.003)$ & $-0.001(0.003)$ \\
\hline Customer concentration & $0.002(0.003)$ & $0.000(0.003)$ & $0.000(0.003)$ & $0.003(0.003)$ & $0.006(0.003)^{* *}$ & $0.003(0.002)$ \\
\hline Hostility & $-0.098(0.100)$ & $-0.139(0.105)$ & $-0.042(0.092)$ & $-0.034(0.101)$ & $0.012(0.082)$ & $-0.017(0.081)$ \\
\hline R\&D on Sales & $-0.948(1.533)$ & $-2.005(1.580)$ & $-0.371(1.383)$ & $-0.953(1.591)$ & $1.411(1.304)$ & $3.102(1.285)^{* *}$ \\
\hline ISO 14000 & $0.969(0.256)^{* * *}$ & $0.879(0.255)^{* * *}$ & $0.530(0.220)^{* *}$ & $0.051(0.248)$ & $-0.302(0.203)$ & $0.102(0.200)$ \\
\hline Sales $(\log )$ & $0.156(0.118)$ & $0.124(0.126)$ & $-0.141(0.114)$ & $-0.002(0.109)$ & $-0.219(0.089)^{* *}$ & $-0.118(0.088)$ \\
\hline$R \& D$ collaboration & $-0.014(0.074)$ & $0.000(0.077)$ & $-0.087(0.068)$ & $0.044(0.077)$ & $0.139(0.063)^{* *}$ & $0.232(0.062)^{* * *}$ \\
\hline Assets & $0.472(0.123)^{* * *}$ & $0.438(0.128)^{* * *}$ & $1.264(0.163)^{* * *}$ & $0.129(0.126)$ & $0.185(0.103)$ & $0.138(0.102)$ \\
\hline Audited firm & $0.236(0.230)$ & $-0.003(0.244)$ & $0.418(0.226)$ & $0.361(0.232)$ & $0.054(0.190)$ & $0.117(0.187)$ \\
\hline ICT & $-0.117(0.158)$ & $-0.104(0.166)$ & $-0.018(0.144)$ & $-0.064(0.160)$ & $0.175(0.131)$ & $0.246(0.129)$ \\
\hline Intangibles to Total Assets & $-0.772(2.645)$ & $-0.149(1.297)$ & $-1.025(2.823)$ & $-2.648(1.304)^{* *}$ & $3.451(1.069)^{* * *}$ & $3.076(1.053)^{* * *}$ \\
\hline Cash to Short Liabilities & $-0.013(0.067)$ & $0.029(0.070)$ & $-0.003(0.062)$ & $-0.012(0.069)$ & $-0.022(0.057)$ & $-0.045(0.056)$ \\
\hline R\&D employees & $0.006(0.029)$ & $0.034(0.030)$ & $0.000(0.025)$ & $-0.013(0.030)$ & $-0.027(0.025)$ & $-0.006(0.024)$ \\
\hline Short-term liabilities & $0.005(0.094)$ & $-0.233(0.099)^{* *}$ & $-0.364(0.104)^{* * *}$ & $-0.148(0.100)$ & $-0.046(0.082)$ & $-0.046(0.081)$ \\
\hline Employees & $-0.015(0.003) * * *$ & $-0.010(0.003)^{* * *}$ & $-0.014(0.002)^{* * *}$ & $-0.001(0.003)$ & $0.000(0.002)$ & $0.000(0.002)$ \\
\hline $\mathrm{R}^{2}$ & 0.381 & 0.317 & 0.531 & 0.192 & 0.456 & 0.488 \\
\hline Adj. $\mathrm{R}^{2}$ & 0.286 & 0.213 & 0.448 & 0.079 & 0.380 & 0.416 \\
\hline F-value & $3.990 * *$ & $3.033 * * *$ & $6.406 * * *$ & $1.700 * *$ & $5.987 * * *$ & $6.803 * * *$ \\
\hline Max. VIF & 4.534 & 4.787 & 5.064 & 4.384 & 4.384 & 4.384 \\
\hline
\end{tabular}

We report standard errors (S.E.) in parentheses. $* *$ and $* * *$ denote significance at the $5 \%$ and $1 \%$ levels, respectively (one-tailed when coefficient sign is predicted, twotailed otherwise). 
Table 7

Additional analyses

\begin{tabular}{|c|c|c|c|c|c|c|}
\hline & \multicolumn{4}{|c|}{ Model 1} & Model 2 & Model 3 \\
\hline & $\begin{array}{c}\text { Change sales per } \\
\text { employee } \\
t+1\end{array}$ & $\begin{array}{c}\text { Change sales per } \\
\text { employee }_{t+2}\end{array}$ & $\begin{array}{c}\text { Change sales per } \\
\text { employee }_{t+3}\end{array}$ & $\begin{array}{c}\text { Perceived } \\
\text { performance }\end{array}$ & $\begin{array}{c}\text { Exploitative } \\
\text { innovation }\end{array}$ & $\begin{array}{c}\text { Exploratory } \\
\text { innovation }\end{array}$ \\
\hline & Coef. (S.E.) & Coef. (S.E.) & Coef. (S.E.) & Coef. (S.E.) & Coef. (S.E.) & Coef. (S.E.) \\
\hline Intercept & $-0.002(0.075)$ & $-0.003(0.074)$ & $-0.002(0.078)$ & $-0.000(0.071)$ & $-0.000(0.070)$ & $-0.000(0.070)$ \\
\hline Use of BSC & $0.081(0.075)$ & $0.158(0.074)^{* *}$ & $0.130(0.079)^{* *}$ & $-0.021(0.071)$ & $0.165(0.070)^{* * *}$ & $0.168(0.070) * * *$ \\
\hline $\mathrm{R}^{2}$ & 0.007 & 0.025 & 0.017 & 0.000 & 0.027 & 0.028 \\
\hline Adj. $R^{2}$ & 0.001 & 0.020 & 0.011 & 0.000 & 0.022 & 0.023 \\
\hline F-value & 1.158 & $4.556^{* * *}$ & $2.749 * *$ & 0.086 & $5.596 * * *$ & $5.804 * * *$ \\
\hline
\end{tabular}

Panel B. Additional analysis. Regression results for hypotheses $\mathrm{H} 2$.

\begin{tabular}{|c|c|c|c|c|c|c|}
\hline & \multicolumn{4}{|c|}{ Model 4} & Model 5 & Model 6 \\
\hline & $\begin{array}{r}\text { Change sales per } \\
\text { employee }_{\mathrm{t}+1} \\
\text { Coef. }(\text { S.E. })\end{array}$ & $\begin{array}{r}\text { Change sales per } \\
\text { employee }_{t+2} \\
\text { Coef. }(S . E .)\end{array}$ & $\begin{array}{r}\text { Change sales per } \\
\text { employee } \\
\text { Coef. }(\text { S.E. })\end{array}$ & $\begin{array}{r}\text { Perceived } \\
\text { performance } \\
\text { Coef. }(\text { S.E. })\end{array}$ & $\begin{array}{r}\text { Exploitative } \\
\text { innovation } \\
\text { Coef. (S.E.) }\end{array}$ & $\begin{array}{r}\text { Exploratory } \\
\text { innovation } \\
\text { Coef. (S.E.) }\end{array}$ \\
\hline Intercept & $0.016(0.074)$ & $0.019(0.073)$ & $0.021(0.077)$ & $0.010(0.071)$ & $-0.002(0.070)$ & $-0.008(0.069)$ \\
\hline Use of BSC & $0.104(0.075)$ & $0.184(0.074)^{* *}$ & $0.155(0.078)^{* *}$ & $-0.011(0.072)$ & $0.173(0.070)^{* * *}$ & $0.205(0.070) * * *$ \\
\hline Development stage & $0.096(0.080)$ & $0.094(0.078)$ & $0.112(0.082)$ & $-0.009(0.073)$ & $0.123(0.072)^{* *}$ & $0.083(0.071)$ \\
\hline Use of BSC * Development stage & $0.200(0.091)^{* *}$ & $0.224(0.089) * * *$ & $0.251(0.091)^{* * *}$ & $0.125(0.084)$ & $-0.026(0.082)$ & $-0.094(0.082)$ \\
\hline $\mathrm{R}^{2}$ & 0.036 & 0.067 & 0.066 & 0.013 & 0.044 & 0.059 \\
\hline Adj. $\mathrm{R}^{2}$ & 0.019 & 0.051 & 0.048 & 0.000 & 0.030 & 0.045 \\
\hline F-value & $2.176^{* *}$ & $4.162 * * *$ & $3.701 * * *$ & 0.852 & $3.036 * *$ & $4.139 * * *$ \\
\hline
\end{tabular}

We report standard errors (S.E.) in parentheses. $* *$ and $* * *$ denote significance at the $5 \%$ and $1 \%$ levels, respectively (one-tailed when coefficient sign is predicted, twotailed otherwise). 